\title{
Histone Deacetylase Inhibitors Protect Against Pyruvate Dehydrogenase Dysfunction in Huntington's Disease
}

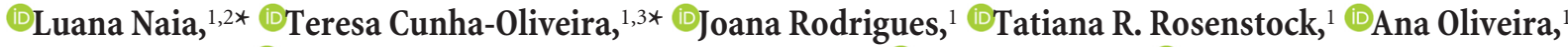 \\ Márcio Ribeiro, ${ }^{1}{ }^{\circledR}$ Catarina Carmo, ${ }^{1}$ Sofia I. Oliveira-Sousa, ${ }^{1}{ }^{\oplus}$ Ana I. Duarte, ${ }^{1,3}{ }^{\odot}$ Michael R. Hayden, ${ }^{4}$ \\ and $\oplus^{-}$A. Cristina Rego ${ }^{1,2}$ \\ ${ }^{1}$ Center for Neuroscience and Cell Biology, University of Coimbra, 3004-504 Coimbra, Portugal, ${ }^{2}$ Faculty of Medicine, University of Coimbra, 3000-548 \\ Coimbra, Portugal, ${ }^{3}$ Institute for Interdisciplinary Research, University of Coimbra, 3030-789 Coimbra, Portugal, and ${ }^{4}$ Centre for Molecular Medicine and \\ Therapeutics, Child and Family Research Institute, University of British Columbia, Vancouver, British Columbia, V5Z 4H4 Canada
}

Transcriptional deregulation and changes in mitochondrial bioenergetics, including pyruvate dehydrogenase (PDH) dysfunction, have been described in Huntington's disease (HD). We showed previously that the histone deacetylase inhibitors (HDACIs) trichostatin A and sodium butyrate $(\mathrm{SB})$ ameliorate mitochondrial function in cells expressing mutant huntingtin. In this work, we investigated the effect of HDACIs on the regulation of PDH activity in striatal cells derived from HD knock-in mice and YAC128 mice. Mutant cells exhibited decreased PDH activity and increased PDH Elalpha phosphorylation/inactivation, accompanied by enhanced protein levels of PDH kinases 1 and 3 (PDK1 and PDK3). Exposure to dichloroacetate, an inhibitor of PDKs, increased mitochondrial respiration and decreased production of reactive oxygen species in mutant cells, emphasizing PDH as an interesting therapeutic target in HD. Treatment with SB and sodium phenylbutyrate, another HDACI, recovered cell viability and overall mitochondrial metabolism in mutant cells. Exposure to SB also suppressed hypoxia-inducible factor-1 (HIF-1 $\alpha$ ) stabilization and decreased the transcription of the two most abundant PDK isoforms, PDK2 and PDK3, culminating in increased PDH activation in mutant cells. Concordantly, PDK3 knockdown improved mitochondrial function, emphasizing the role of PDK3 inactivation on the positive effects achieved by SB treatment. YAC128 mouse brain presented higher mRNA levels of PDK1-3 and PDH phosphorylation and decreased energy levels that were significantly ameliorated after SB treatment. Furthermore, enhanced motor learning and coordination were observed in SB-treated YAC128 mice. These results suggest that HDACIs, particularly SB, promote the activity of $\mathrm{PDH}$ in the HD brain, helping to counteract HD-related deficits in mitochondrial bioenergetics and motor function.

Key words: Huntington disease; metabolism; mitochondria; PDH kinase; pyruvate dehydrogenase; sodium butyrate

\section{Significance Statement}

The present work provides a better understanding of mitochondrial dysfunction in Huntington's disease (HD) by showing that the pyruvate dehydrogenase $(\mathrm{PDH})$ complex is a promising therapeutic target. In particular, the histone deacetylase inhibitor sodium butyrate (SB) may indirectly (through reduced hypoxia-inducible factor 1 alpha stabilization) decrease the expression of the most abundant PDH kinase isoforms (e.g., PDK3), ameliorating PDH activity and mitochondrial metabolism and further affecting motor behavior in HD mice, thus constituting a promising agent for HD neuroprotective treatment.

\section{Introduction}

Huntington's disease (HD) is an autosomal-dominant neurodegenerative disease characterized by the expression of mutant

Received May 17, 2014; revised Dec. 22, 2016; accepted Dec. 30, 2016.

Author contributions: L.N., T.C.-0., and A.C.R. designed research; L.N., T.C.-0., J.R., T.R.R., A.O., M.R., C.C., S.I.0.S., and A.I.D. performed research; M.R.H. and A.C.R. contributed unpublished reagents/analytic tools; L.N., T.C.-O., J.R., T.R.R., A.I.D., and A.C.R. analyzed data; L.N., T.C.-O., and A.C.R. wrote the paper.

This work was supported by projects PTDC/SAU-FCF/108056/2008, EXPL/BIM-MEC/2220/2013, PEst-C/SAU/ LA0001/2013-2014, and UID/NEU/04539/2013 funded by Fundação para a Ciência e a Tecnologia (FCT), Portugal, cofinanced by Programa Operacional Competitividade e Internacionalização (COMPETE), Quadro de Referência Estratégica Nacional (QREN), European Union (Fundo Europeu de Desenvolvimento Regional); Santa Casa da Misericórdia de Lisboa (SCML), Mantero Belard Neuroscience Prize (first edition); and Fundação Luso-Americana huntingtin (mHTT), bearing an expanded polyglutamine tract in its N-terminus, and progressive loss of striatal and cortical neurons (Gil and Rego, 2008). Among several targets, mHTT affects mitochondrial homeostasis (Gil and Rego, 2008) and disturbs para 0 Desenvolvimento (FLAD) Life Science 2020 project. T.C.-0. and T.R.R. were supported by FCT postdoctoral fellowships SFRH/BPD/34711/2007 and SFRH/BPD/44246/2008, respectively; M.R. and L.N. were supported by the doctoral fellowships SFRH/BD/41285/2007 and SFRH/BD/86655/2012, respectively, cofinanced by the Programa Operacional Potencial Humano, QREN, and the European Union. We thank Dr. Henrique Girão (Institute for Biomedical Imaging and Life Sciences, Faculty of Medicine, University of Coimbra) for kindly providing the antibody against HIF- $1 \alpha$.

The authors declare no competing financial interests.

*L.N. and T.C.-O. contributed equally to this work. 
gene expression by interfering with nuclear transcription (co)factors (Zhai et al., 2005; Benn et al., 2008), some linked to mitochondrial biogenesis and function (Cui et al., 2006; Cunha-Oliveira et al., 2012). mHTT also affects mitochondrial transmembrane potential (Naia et al., 2015), calcium-buffering capacity (Damiano et al., 2010), oxidative phosphorylation (Schatz, 1995; Milakovic and Johnson, 2005), and the production of reactive oxygen species (ROS) that originate in mitochondria (Ribeiro et al., 2014).

Symptomatic and presymptomatic HD patients evidence altered brain glucose metabolism in the caudate, putamen, cortex, and CSF (Kuhl et al., 1982; Kuwert et al., 1989; Jenkins et al., 1993; Koroshetz et al., 1997). The onset of energy and mitochondrial modifications at presymptomatic stages suggest that energy deficits may constitute early phenomena in HD pathogenesis (Mochel and Haller, 2011). Previously, we observed reduced activity of complex I in mitochondria from platelets of presymptomatic and symptomatic HD carriers (Silva et al., 2013). Moreover, bioenergetic dysfunction in HD human cybrids was associated with decreased pyruvate dehydrogenase $(\mathrm{PDH})$ activity and protein levels and increased phosphorylation/inactivation of the E1alpha subunit (Ferreira et al., 2011). PDH was shown to be impaired in HD human brains (Sorbi et al., 1983; Butterworth et al., 1985) and the PDH indirect activator dichloroacetate (DCA) showed protective effects in HD mouse models (Andreassen et al., 2001), revealing $\mathrm{PDH}$ as a central player in $\mathrm{HD}$-associated mitochondrial dysfunction. This is in agreement with the observation of elevated lactate levels in the striatum of presymptomatic HD patients (Jenkins et al., 1998), which suggests the occurrence of $\mathrm{PDH}$ defects in vivo. The PDH complex (PDC) is a large complex of three functional enzymes, E1, E2, and E3, and the current understanding of PDC regulation involves inhibitory serine phosphorylation of $\mathrm{PDH}$ Elalpha by specific $\mathrm{PDH}$ kinases (PDKs), whereas dephosphorylation of PDH Elalpha by $\mathrm{PDH}$ phosphatases (PDPs) activates the PDC (Harris et al., 2002; Patel and Korotchkina, 2006). Importantly, the activity of PDKs may be regulated at the transcriptional level (Kim et al., 2006; Patel and Korotchkina, 2006), suggesting that PDC dysfunction may be related to transcriptional deregulation in HD.

Gene transcription is generally favored by histone acetylases, whereas histone deacetylases (HDACs) mainly repress gene expression (Struhl, 1998), similarly to mHTT. Previous studies indicated that HDAC inhibitors (HDACIs) ameliorate the transcriptional changes in HD (Zuccato et al., 2010). A phase I clinical trial with the HDACI sodium phenylbutyrate (PB) showed recovery of expression of 12 transcripts that were upregulated in untreated HD patients (Borovecki et al., 2005; Hogarth et al., 2007; Brett et al., 2014). In addition, we showed previously that mHTT induced deficits in mitochondrial calcium handling, which was ameliorated by treatment with HDACIs, namely trichostatin A (TSA), a pan-lysine HDACI, and sodium butyrate (SB), which acts on class I and IIa HDACs, preferentially modulating Lys acetylation sites in the nucleus (Oliveira et al., 2006; Schölz et al., 2015), similarly to PB. Therefore, in the present work, we analyzed the influence of TSA, SB, and PB in improving PDC function in striatal cells expressing full-length $\mathrm{mHTT}$ and confirmed the effect of SB in YAC128 mouse model. Our results suggest that the HDACI SB promotes PDH activity in both in vitro and

Correspondence should be addressed to Ana Cristina Rego, Ph.D., Center for Neuroscience and Cell Biology, and Faculty of Medicine, Rua Larga University of Coimbra, polo I, 3004-504 Coimbra, Portugal. E-mail: a.cristina.rego@gmail.com or acrego@cnc.uc.pt.

DOI:10.1523/JNEUROSCI.2006-14.2016

Copyright $(2017$ the authors $\quad 0270-6474 / 17 / 372777-19 \$ 15.00 / 0$ ex vivo models by regulating the expression of PDKs, helping to counteract HD-related deficits in mitochondrial function. In addition, SB improved brain mitochondrial bioenergetics and positively influenced motor learning and coordination in YAC128 mice.

\section{Materials and Methods \\ Materials}

Fetal bovine serum (FBS) and penicillin/streptomycin were from Invitrogen. DMEM, Opti-MEM, bovine serum albumin (BSA), trypan blue $(0.4 \%)$, nicotinamide adenine dinucleotide hydrate (NAD), coenzyme A (CoA), carbonyl cyanide 4-(trifluoromethoxy) phenylhydrazone (FCCP), thiamine pyrophosphate $\left(\mathrm{TPP}^{+}\right)$, pyruvate, acetyl-L-carnitine (ALCAR), DCA, TSA, SB, and PB were from Sigma Aldrich. Calcium chloride and $\mathrm{MgCl}_{2}$ were from Merck. PureZOL RNA isolation reagent, iScript cDNA Synthesis kit, SsoFast EvaGreen Supermix, Protein Assay and PVDF membranes were from Bio-Rad. The Phospho-PDH in-cell ELISA kit and NAD/NADH kit were from Abcam. Lipofectamine 3000 was from Thermo Fisher Scientific. The XF Cell Mito Stress Test Kit and XF24 cell culture microplates were from Seahorse Bioscience. Miniosmotic pumps were from Alzet. Isoflurane was from Esteve. All other reagents were of analytical grade.

\section{Cell culture and treatments}

Immortalized striatal neurons derived from knock-in mice expressing fulllength normal (STHdh ${ }^{7 / 7}$, clone 2aA5, RRID:CVCL_M590, referred as wildtype cells) or full-length $\mathrm{mHtt}$ with 111 glutamines (STHdh ${ }^{111 / 111}$, clone 109-1A, RRID:CVCL_M591, referred as mutant cells) were generously provided by Dr. Marcy MacDonald (Massachusetts General Hospital, Charleston, MA) and treated according to slight modifications of established procedures (Trettel et al., 2000). Briefly, cells were grown adherent at $33^{\circ} \mathrm{C}$ in DMEM supplemented with 10\% FBS, 4 mM glutamine, $100 \mathrm{U} / \mathrm{ml}$ penicillin, $0.1 \mathrm{mg} / \mathrm{ml}$ streptomycin, and $400 \mathrm{~g} / \mathrm{ml}$ geneticin in an atmosphere of $95 \%$ air/5\% $\mathrm{CO}_{2}$. Twenty-four hours before the experiment (and $1 \mathrm{~d}$ after cell plating), the cells were incubated with TSA (10,50, and $100 \mathrm{~nm}), \mathrm{SB}(100$, 250 , and $500 \mu \mathrm{M}), \operatorname{PB}(100,250$, and $500 \mu \mathrm{M}), \operatorname{ALCAR}(100 \mu \mathrm{M}, 500 \mu \mathrm{M}$, and $5 \mathrm{~mm})$, or DCA ( $300 \mu \mathrm{M}, 1 \mathrm{~mm}$, and $3 \mathrm{~mm})$.

For hypoxia-inducible factor 1 alpha (HIF- $1 \alpha$ ) stabilization/accumulation, striatal cells were maintained for $1 \mathrm{~h}$ before the experiment in a controlled hypoxic atmosphere $\left(0.1 \%-0.5 \% \mathrm{O}_{2}\right.$; Forma Anaerobic System, Thermo Fisher Scientific) at $33^{\circ} \mathrm{C}$. The HIF- $1 \alpha$ subunit is continuously synthesized and degraded under normoxic conditions, but accumulates rapidly after exposure to low oxygen tensions (Salceda and Caro, 1997).

\section{Constructs and transfection}

Immortalized striatal cells were cultured in DMEM supplemented with $10 \%$ FBS and transfected on the following day ( $80 \%$ confluence) with the pLKO.1/shRNA-PDK3 vector (clone ID: TRCN0000023835; Dharmacon), designed by the RNAi Consortium, or the pLKO.1-scrambled negative control (TRC-RHS6848; Open Biosystems). STHdh cells were transfected with $0.75 \mu \mathrm{g}$ of DNA $/ \mathrm{cm}^{2}$ of growth area in opti-MEM without FBS or antibiotics, following the Lipofectamine 3000 (ThermoFisher Scientific) manufacturer instructions. Medium was changed $4 \mathrm{~h}$ after transfection and cells were cultured for $48 \mathrm{~h}$.

\section{Total cell extracts}

Adherent cells were washed 2 times in ice-cold PBS containing the following (in mM): $137 \mathrm{NaCl}, 2.7 \mathrm{KCl}, 1.8 \mathrm{KH}_{2} \mathrm{PO}_{4}, 10 \mathrm{Na}_{2} \mathrm{HPO}_{4} \cdot 2 \mathrm{H}_{2} \mathrm{O}$, $\mathrm{pH} 7.4$, and then scraped in $500 \mu \mathrm{l}$ of lysis buffer ( $150 \mathrm{~mm} \mathrm{NaCl}, 50 \mathrm{~mm}$ Tris, 5 mm EGTA, 1\% Triton X-100; 0.5\% deoxycholate, 0.1\% SDS, pH 7.5) supplemented with $1 \mathrm{~mm}$ DTT, $1 \mathrm{~mm}$ PMSF, $1 \mu \mathrm{g} / \mathrm{ml}$ protease cocktail inhibitor (containing chymostatin, pepstatin A, leupeptin, and antipain), $1 \mu \mathrm{M}$ TSA (HDAC inhibitor), and $10 \mathrm{~mm}$ nicotinamide (sirtuins inhibitor). Cellular extracts were frozen three times in liquid nitrogen and then sonicated for $30 \mathrm{~s}$ and centrifuged at $20,800 \times g$ for $10 \mathrm{~min}$ (Eppendorf Centrifuge 5417R) to remove cell debris. The pellet was discarded, the supernatant (total extract) collected, and the protein content 
quantified with the Bio-Rad protein assay. Extracts were stored at $-20^{\circ} \mathrm{C}$ until being used for Western blotting experiments.

For the analysis of PDH activity, cell extracts were obtained by scraping the cells using $100 \mu \mathrm{l}$ of buffer containing $25.0 \mathrm{mM} \mathrm{KH}_{2} \mathrm{PO}_{4}, 0.5 \mathrm{~mm}$ EDTA, pH 7.25, supplemented with $0.01 \%$ Triton X-100.

\section{$N A D^{+} / N A D H$ quantification}

The total levels of $\mathrm{NAD}^{+}$and NADH were measured using a commercially available kit (Abcam) following the manufacturer's instructions. Briefly, cells were plated in six-well plates and cell extracts were obtained with NADH/NAD extraction buffer. The samples were frozen three times in liquid nitrogen and centrifuged at 20,800 $\times \mathrm{g}$ for $10 \mathrm{~min}$ (Eppendorf Centrifuge 5417R) to remove cell debris. The extracted samples were divided in two: one remained in ice (total NAD) and the other one was heated to $60^{\circ} \mathrm{C}$ for $30 \mathrm{~min}$ to decompose $\mathrm{NAD}^{+}(\mathrm{NADH})$. Both samples were transferred to a 96 -well plate and a $\mathrm{NAD}^{+}$-cycling mixture enzyme was added and incubated at room temperature for $5 \mathrm{~min}$ to convert $\mathrm{NAD}^{+}$to NADH. Finally, NADH developer was added into each well and the reaction occurred at room temperature for $2 \mathrm{~h}$. Absorbance was monitored using a microplate reader Spectra Max Plus 384 (Molecular Devices) at $450 \mathrm{~nm}$.

\section{PDH activity assay}

$\mathrm{PDH}$ activity was assayed at $30^{\circ} \mathrm{C}$ by measuring the reduction of $\mathrm{NAD}^{+}$ at $340 \mathrm{~nm}$ in a Spectra Max Plus 384 microplate reader (Molecular Devices) upon mixing $9 \mu \mathrm{g}$ of protein with $0.5 \mathrm{mM} \mathrm{NAD}^{+}$in the presence of $200 \mu \mathrm{M} \mathrm{TPP}{ }^{+}, 40 \mu \mathrm{M} \mathrm{CoA}$, and $4.0 \mathrm{~mm}$ pyruvate. The assay was performed in the presence of $2.5 \mu \mathrm{M}$ rotenone to prevent NADH consumption by complex I (Zhou et al., 2009). PDH activity was calculated as absorbance units per minute per milligram of protein and converted to the percentage of wild-type control cells.

\section{Determination of PDH Elalpha subunit protein levels and phosphorylation}

$\mathrm{PDH}$ expression and phosphorylation were assessed using the PhosphoPDH In-Cell ELISA kit from Abcam and following the manufacturer's instructions. Briefly, cells were plated in 96-well plates, transfected with shRNA-PDK3 or scramble shRNA control or incubated with the HDACI compounds, and fixed with 3.7\% formaldehyde in PBS. Cells were permeabilized, blocked, and incubated overnight with an antibody against total PDH E1alpha, combined with another antibody against one of the phosphorylated forms of PDH E1alpha at Ser293 (site 1), Ser300 (site 2), or Ser232 (site 3). Separate secondary antibodies were used against PDH E1alpha or the phosphorylated serines and developed by dual colorimetric detection. Cell density was normalized after Janus green staining. Absorbance was monitored using a microplate reader Spectra Max Plus 384 (Molecular Devices).

\section{Cell viability assessment}

At the time of cell incubation with the different compounds, the culture medium was replaced for fresh medium. The nuclear morphology of the striatal wild-type and mutant cells exposed to different concentrations of the compounds (TSA, PB, SB, ALCAR, and DCA) was analyzed by fluorescence microscopy using a double-staining procedure with Hoechst 33342 and propidium iodide (PI). After a washing step with saline medium containing the following (in $\mathrm{mm}$ ): $120 \mathrm{NaCl}, 3.5 \mathrm{KCl}, 0.4 \mathrm{KH}_{2} \mathrm{PO}_{4}$, 20 HEPES, $5 \mathrm{NaHCO}_{3}, 1.2 \mathrm{Na}_{2} \mathrm{SO}_{4}$, and 15 glucose, the cells were incubated with $4 \mu \mathrm{g} / \mathrm{ml}$ Hoechst 33342 for $15 \mathrm{~min}$, washed 2 times with saline medium, and incubated with $4 \mu \mathrm{g} / \mathrm{ml}$ PI for $3 \mathrm{~min}$ in the dark at room temperature. Cells were washed three times in saline medium to remove extracellular dyes and further examined and scored as depicted in Figure 2 by analyzing images taken in the AxioObserver $Z 1$ upright microscope (Zeiss).

\section{Analysis of oxidative stress}

Cells (plated in 96-well plates) were loaded for $30 \mathrm{~min}$ with $20 \mu \mathrm{M}$ dihydro-dichlorofluorescein diacetate $\left(\mathrm{DCFH}_{2}-\mathrm{DA}\right)$, a stable, nonfluorescent, cell-permeable compound, at $33^{\circ} \mathrm{C}$ in $\mathrm{Na}^{+}$medium containing the following (in mM): $135 \mathrm{NaCl}, 5 \mathrm{KCl}, 0.4 \mathrm{KH}_{2} \mathrm{PO}_{4}, 1.8 \mathrm{CaCl}_{2}, 20$ HEPES, and 5.5 glucose, $\mathrm{pH}$ 7.4. When internalized by the cell,
$\mathrm{DCFH}_{2}-\mathrm{DA}$ is hydrolyzed to DCFH by intracellular esterases, retained inside the cell, and rapidly oxidized to the highly green fluorescent compound 2,7-dichlorofluorescein (DCF), a redox indicator probe that responds to changes in intracellular iron signaling and peroxynitrite formation (Kalyanaraman et al., 2012). DCF fluorescence (480 nm excitation, $550 \mathrm{~nm}$ emission) was monitored continuously for $1 \mathrm{~h}$ at $33^{\circ} \mathrm{C}$ using a Spectrofluorometer Gemini EM (Molecular Devices) microplate reader. DCF fluorescence was corrected for variations in total protein content in the wells after quantification of cell protein in each well by the Bio-Rad protein assay.

\section{Oxygen consumption rate (OCR) measurements}

Oxygraph oxygen electrode. To measure the OCR, cells were plated in 75 $\mathrm{cm}^{2}$ flasks and incubated on the following day in the absence or presence of $500 \mu \mathrm{M} \mathrm{SB}, 250 \mu \mathrm{M} \mathrm{PB}$, or $3 \mathrm{~mm}$ DCA for $24 \mathrm{~h}$. Cells were detached by trypsinization and trypsin was inactivated by adding culture medium containing FBS. The cells were then washed in prewarmed $\left(33^{\circ} \mathrm{C}\right)$ respiration buffer containing the following (in $\mathrm{mM}$ ): $132 \mathrm{NaCl}, 4 \mathrm{KCl}, 1 \mathrm{CaCl}_{2}$, $1.2 \mathrm{NaH}_{2} \mathrm{PO}_{4}, 1.4 \mathrm{~mm} \mathrm{MgCl}_{2}, 6$ glucose, and 10 HEPES, pH 7.4, and resuspended in $300 \mu \mathrm{l}$ of respiration buffer. The rate of $\mathrm{O}_{2}$ consumption was recorded under constant magnetic stirring in an Oxygraph DW1 oxygen electrode chamber (Hansatech Instruments) previously calibrated for the oxygen dissolved at $33^{\circ} \mathrm{C}$ in oxygenated water (maximum) and in $\mathrm{N}_{2}$-saturated water (minimum). After recording the basal rate of oxygen consumption, cells were sequentially exposed to oligomycin (10 $\mu \mathrm{g} / \mathrm{ml})$ to avoid the reversal of ATP synthase and FCCP $(2.5 \mu \mathrm{M})$ to assess maximal respiration rates. Potassium cyanide $(\mathrm{KCN})(700 \mu \mathrm{M})$ was then added to confirm mitochondrial $\mathrm{O}_{2}$ consumption, manifested as a decrease in $\mathrm{O}_{2}$ consumption due to inhibition of mitochondrial complex IV. At the end of the experiment, the cells were pelleted, resuspended in $1 \mathrm{M} \mathrm{NaOH}$, and protein was quantified by the Bio-Rad protein assay. Results are expressed in nanomoles of $\mathrm{O}_{2}$ per minute per milligram of protein.

Cell respirometry. OCR of transfected striatal cells was measured using the XF24 flux analyzer (Seahorse Bioscience) following the manufacturer's instructions. Striatal cells were grown on the 24-well custom plates at 30,000 cells per well and transfected $48 \mathrm{~h}$ before the experiment (as described in the "Constructs and transfection" session) or incubated with $500 \mu \mathrm{M}$ SB $24 \mathrm{~h}$ before the experiment. Before running the experiment, cell culture medium was removed and cells were washed once with $1 \mathrm{ml}$ of DMEM 5030 medium, $\mathrm{pH} 7.4$, supplemented with $4.5 \mathrm{~g} / \mathrm{L}$ glucose and $4 \mathrm{~mm}$ glutamine and then incubated in $450 \mu \mathrm{l}$ of supplemented $\mathrm{DMEM}$ at $33^{\circ} \mathrm{C}$ in a $\mathrm{CO}_{2}$-free incubator for $1 \mathrm{~h}$. Four baseline measurements of OCR were sampled before sequential injection of mitochondrial inhibitors and four metabolic determinations were sampled after the addition of each mitochondrial inhibitor before injection of the subsequent inhibitors. The mitochondrial inhibitors used were oligomycin A $(1 \mu \mathrm{M}), \operatorname{FCCP}(0.9 \mu \mathrm{M})$, and antimycin A $(1 \mu \mathrm{M})$ plus rotenone $(1 \mu \mathrm{M})$. OCR was automatically calculated and recorded using Seahorse Bioscience software. After the assays, the protein level was determined for each well to confirm equal cell density per well. Results are expressed in picomoles of $\mathrm{O}_{2}$ per minute per microgram of protein.

\section{YAC128 mice surgery}

YAC128 mice, described previously by Slow et al. (2003), express fulllength mutant HTT with $\sim 128$ CAG repeats from a yeast artificial chromosome (YAC) transgene (RRID: MGI_MGI:3613515). YAC128 (line HD53) and wild-type mice were housed in the housing facility of the Center for Neuroscience and Cell Biology and Faculty of Medicine at the University of Coimbra (Coimbra, Portugal) under conditions of controlled temperature $\left(22-23^{\circ} \mathrm{C}\right)$ and under a $12 \mathrm{~h} \mathrm{light} / 12 \mathrm{~h}$ dark cycle with lights on at 07:00 h. All studies were performed according to the Helsinki Declaration and the Guide for the Care and Use of Laboratory Animals from the National Institutes of Health. Food and water were available ad libitum throughout the experiment. Animals used in this study (total of 9-13 9-month-old male mice per treatment) were maintained in accordance with the guidelines of the Institutional Animal Care and Use of Committee and were performed in accordance with the European Community directive (2010/63/EU). All efforts were made to minimize ani- 
mal suffering and to reduce the number of animals used. Animals were subjected to small surgeries for the subcutaneous implantation (and removal) of mini-osmotic pumps (28 d pumps, model 2004; Alzet). Each pump was filled with saline $(0.9 \% \mathrm{NaCl})$ or $\mathrm{SB}(1 \mathrm{mg} / \mathrm{kg} / \mathrm{d})$ diluted in saline solution. For the subcutaneously implantation of the pumps, animals were anesthetized with isofluorane using a vaporizer apparatus (EZ Anesthesia) and immediately afterward received a subcutaneous injection of butorphanol $(1: 50 ; 2.5 \mathrm{ml} / \mathrm{kg})$, a morphine-type synthetic opioid analgesic. Animals were kept with the pumps for $30 \mathrm{~d}$ ( 2 more days than the treatment itself because, in order to start releasing the solutions, the pump needs to be at the same temperature as the animal's body). To remove the pumps, mice were subjected to the same surgical procedure as described above. The body weight was measured for all animals after treatment. Behavior analysis was performed $2 \mathrm{~d}$ after the surgery (recovery period).

\section{Rotarod motor evaluation}

Mice were allowed to adapt to the behavior test room for $2 \mathrm{~h}$ before the behavior studies. Procedures were consistent for all subjects and tests made at minimum noise levels. Motor coordination and motor learning were assessed on a rotarod apparatus (Letica Scientific Instruments) using a previously described procedure (Naia et al., 2016b). Behavior equipment was cleaned thoroughly with $70 \%$ ethanol before each animal trial. Separate cohorts of mice were trained at a fixed speed of 4 rotations per minute $(\mathrm{rpm})$ to a maximum time of $40 \mathrm{~s}$. The training time (motor learning) corresponds to the time it took the mice to stand on the rod without falling for 40 consecutive seconds. Motor coordination and balance were assessed using the accelerating rotarod task after all of the animals learned the previous task. In this test, the rotarod accelerated from 5 to $40 \mathrm{rpm}$ over $5 \mathrm{~min}$ and the latency to fall was recorded for each of the four trials for each mouse. Resting time between each trial was set for $30 \mathrm{~min}$.

Total fractions of YAC128 mice cortex

Total fractions from cerebral cortex were obtained from SB or salinetreated YAC128 and wild-type mice brains. Animals were killed by very rapid decapitation in accordance to European Union guideline 86/609/ EEC and Annex II of Portuguese Law No. 113/2013. Mice brains were collected and the cortex from one brain hemisphere was dissected on ice $\left(0-4^{\circ} \mathrm{C}\right)$ and homogenized in lysis buffer, as described for total cell extracts, which was supplemented with $100 \mathrm{~nm}$ okadaic acid, $25 \mathrm{~mm} \mathrm{NaF}, 1$ mм $\mathrm{Na}_{3} \mathrm{VO}_{4}, 1 \mathrm{~mm}$ DTT, 1 mм PMSF, $1 \mu \mathrm{g} / \mathrm{ml}$ protease inhibitor mixture (chymostatin, pepstatin A, leupeptin, and antipain), $1 \mu \mathrm{M}$ TSA (HDACI) plus $10 \mathrm{~mm}$ nicotinamide (sirtuins inhibitor) at $4^{\circ} \mathrm{C}$. Samples were then incubated on ice for $30 \mathrm{~min}$ and centrifuged at $20,800 \times g$ for $10 \mathrm{~min}$ at $4^{\circ} \mathrm{C}$ to discard intact organelles and dead cells. All samples were kept at $-80^{\circ} \mathrm{C}$ until use.

\section{Western blotting}

Total extracts, obtained as described previously, were denatured with denaturing buffer $(50 \mathrm{~mm}$ Tris- $\mathrm{HCl} \mathrm{pH} 6.8,2 \%$ SDS, 5\% glycerol, 600 mM DTT, and $0.01 \%$ bromophenol blue) at $95^{\circ} \mathrm{C}$, for 5 min. Equivalent amounts of protein were separated by $7.5-12 \%$ SDS-PAGE gel electrophoresis and electroblotted onto PVDF membranes (Bio-Rad). The membranes were blocked for $1 \mathrm{~h}$ in Tris-buffered saline (TBS) solution containing $0.1 \%$ Tween (TBS-Tween) and $5 \%$ fat-free milk or $5 \%$ BSA, followed by an overnight incubation with primary antibodies (Table 1) at $4^{\circ} \mathrm{C}$ with gentle agitation. Membranes were then washed 3 times for 15 min each time with TBS-Tween and incubated with secondary antibodies conjugated with alkaline phosphatase $(1: 20,000)$ for $1 \mathrm{~h}$ at room temperature with gentle agitation. Immunoreactive bands were visualized after incubation with ECF substrate (GE Healthcare), which is converted into a highly fluorescent product reagent by alkaline phosphatase. This product strongly fluoresces at 540-560 $\mathrm{nm}$ when the blots are illuminated with UV light (maximum excitation at $430 \mathrm{~nm}$ ) in a Versa Doc 3000 Imaging System (Bio-Rad). Bands were quantified using Quantity One software (Bio-Rad).

Measurement of intracellular levels of adenine nucleotides

Striatal cells were washed and then scraped with ice-cold PBS and cortex from one mouse brain hemisphere was homogenized with ice-cold PBS.
Table 1. List of the primary antibodies used in this work

\begin{tabular}{|c|c|c|c|c|}
\hline Primary antibody & $\begin{array}{l}\text { Molecular } \\
\text { weight } \\
(\mathrm{kDa})\end{array}$ & Reference & Dilution & $\begin{array}{l}\text { Host } \\
\text { species }\end{array}$ \\
\hline Anti-acetyl-histone 3 & 17 & 06-599 (Millipore, RRID:AB_2115283) & 1:750 & Rabbit \\
\hline Anti-histone 3 & 17 & $\begin{array}{l}\text { \#9715 (Cell Signaling Technology, RRID: } \\
\quad \text { AB_331563) }\end{array}$ & $1: 2000$ & Rabbit \\
\hline $\begin{array}{l}\text { Anti-PDH kinase } 1 \\
\text { (PDK1) }\end{array}$ & 47 & $\begin{array}{l}\text { \#3820 (Cell Signaling Technology, RRID: } \\
\text { AB_1904078) }\end{array}$ & $1: 1000$ & Rabbit \\
\hline $\begin{array}{l}\text { Anti-PDK kinase } 3 \\
\text { (PDK3) }\end{array}$ & 47 & ab182574 (Abcam, RRID: AB_2631347) & $1: 1000$ & Rabbit \\
\hline $\begin{array}{l}\text { Anti-pSer232 } \\
\text { PDH-E1 } \alpha\end{array}$ & 44 & AP1063 (Millipore, RRID: AB_10616070) & $1: 750$ & Rabbit \\
\hline Anti-PDH-E1 $\alpha$ & 43 & $\begin{array}{l}\text { \#2784 (Cell Signaling Technology, RRID: } \\
\text { AB_2162928) }\end{array}$ & $1: 1000$ & Rabbit \\
\hline $\begin{array}{l}\text { Anti-PDH } \\
\text { phosphatase } \\
\text { (PDPC) }\end{array}$ & 53 & sc-87354 (Santa Cruz, RRID: AB_2017921) & $1: 200$ & Goat \\
\hline Anti-HIF-1 $\alpha$ & $\sim 130$ & Ab1 (Abcam, RRID: AB_296474) & $1: 500$ & Mouse \\
\hline Anti-tubulin & 50 & T6199 (Sigma-Aldrich, RRID: AB_477583) & $1: 1000$ & Mouse \\
\hline Anti- $\beta$-actin & 42 & A5316 (Sigma-Aldrich, RRID: AB_476743) & 1:5000 & Mouse \\
\hline
\end{tabular}

Table 2. Sequence $\left(5^{\prime}-3^{\prime}\right)$ of primers used for $q R T-P C R$ experiments

\begin{tabular}{llll}
\hline Gene & Accession no. & Forward primer & Reverse primer \\
\hline PDHA1 & NM_008810 & TCATCACTGCCTATCGAGCAC & GTTGCCTCCATAGAAGTTCTTGG \\
PDK1 & NM_172665 & GGACTTGGGTCAGTGAATGC & CGCAGAAACATAAACGAGGTCT \\
PDK2 & NM_133667.2 & CGGACTCTAAGCCAGTTCACA & GTGGGCACCACGTCATTGT \\
PDK3 & NM_145630.2 & CCGTCGCCACTGTCTATCAA & TGCGCAGAAACATATAGGAAGTTT \\
PDK4 & NM_013743.2 & CCGCTTAGTGAACACTCCTCC & TCTACAAACTCTGACAGGGCTTT \\
PDP1 & NM_001098231.1 & CGGGCACTGCTACCTATCCTT & ACAATTTGGACGCCTCCTTACT \\
& NM_001098230.1 & & \\
& NM_001033453.3 & & \\
PDP2 & NM_001024606.1 & GGCTGAGCATTGAAGAAGCATT & GCCTGGATTTCTAGGGAGATGT \\
TBP & NM_013684.3 & ACCGTGAATCTTGGTGTAAC & TCAGCATTTCTTGCACGAAGT \\
\hline
\end{tabular}

The same volume of $0.6 \mathrm{M}$ perchloric acid supplemented with $25 \mathrm{~mm}$ EDTA-Na ${ }^{+}$was added. Extracts were then centrifuged at $20,800 \times g$ for $2 \mathrm{~min}$ at $4^{\circ} \mathrm{C}$ to remove cell debris. The resulting pellet was solubilized with $1 \mathrm{M} \mathrm{NaOH}$ and further analyzed for total protein content by the Bio-Rad protein assay. After neutralization with $10 \mathrm{~m} \mathrm{KOH} / 1.5 \mathrm{~m}$ Tris, samples were centrifuged at $20,800 \times g$ for $5 \mathrm{~min}$ at $4^{\circ} \mathrm{C}$. The resulting supernatants were assayed for ATP, ADP, and AMP determination by separation in a reverse-phase high-performance liquid chromatography with detection at $254 \mathrm{~nm}$. The chromatographic apparatus used was a Beckman-System Gold controlled by a computer. The detection wavelength was $254 \mathrm{~nm}$ and the column used was a Lichrospher $100 \mathrm{RP}-18$ (5 $\mu \mathrm{m})$. An isocratic elution with $100 \mathrm{~mm}$ phosphate buffer $\left(\mathrm{KH}_{2} \mathrm{PO}_{4}\right), \mathrm{pH}$ 6.5 , and $1 \%$ methanol was performed with a flow rate of $1 \mathrm{ml} / \mathrm{min}$. Peak identity was determined by following the retention time of standards. Energy charge was used as a measurement of general energy status of mice cortex, taking into account ATP, ADP, and AMP concentrations, and was calculated according to the following formula: (ATP + $\left.1 / 2^{\star} \mathrm{ADP}\right) /(\mathrm{ATP}+\mathrm{ADP}+\mathrm{AMP})$.

\section{Analysis of gene expression by $q R T-P C R$}

Total RNA was extracted with TRIzol reagent (Life Technologies) for cell extracts or with Purezol (Bio-Rad) for tissue extracts, following the manufacturers' protocols, and quantified using a Nanodrop 2000 (Thermo Fisher Scientific), confirming that A260/280 and A260/230 were $>1.9$. RNA integrity was verified with the Experion RNA StdSens kit (Bio-Rad) for cell extracts or by $1.0 \%$ agarose gel electrophoresis for tissue extracts and RNA was converted into cDNA using the iScript cDNA synthesis kit (Bio-Rad) following the manufacturer's instructions. qRT-PCR was performed using the SsoFast Eva Green Supermix in a CFX96 real-time PCR system (Bio-Rad), with the primers defined in Table 2 at $500 \mathrm{~nm}$ (for cell extracts) or $300 \mathrm{~nm}$ (for tissue extracts). Amplification of $12.5 \mathrm{ng}$ (for cell 
A

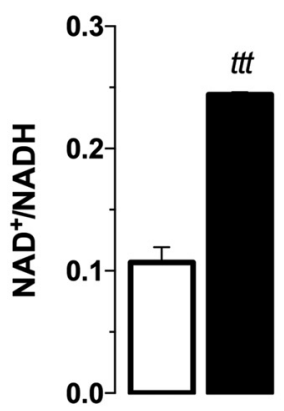

E

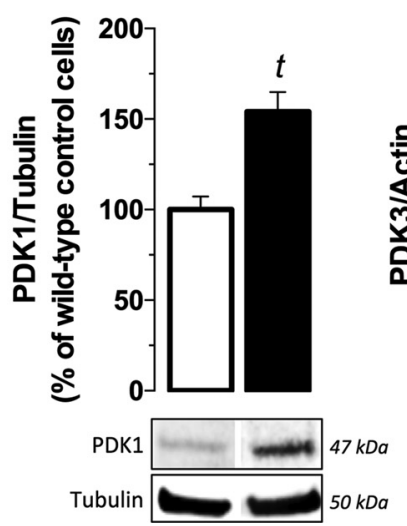

B

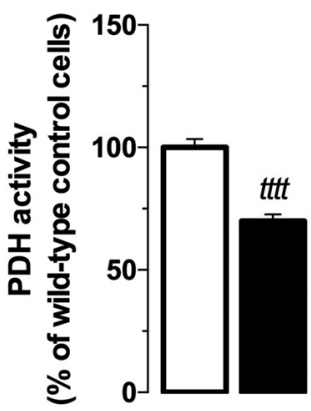

$\mathbf{F}$

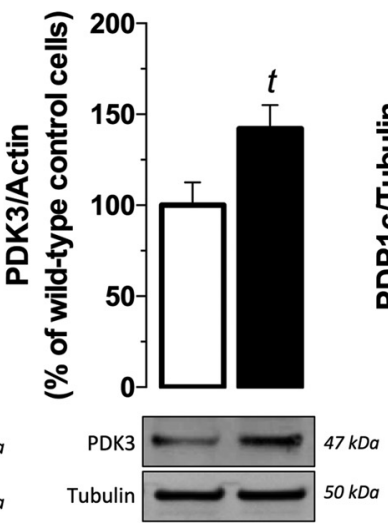

C

G
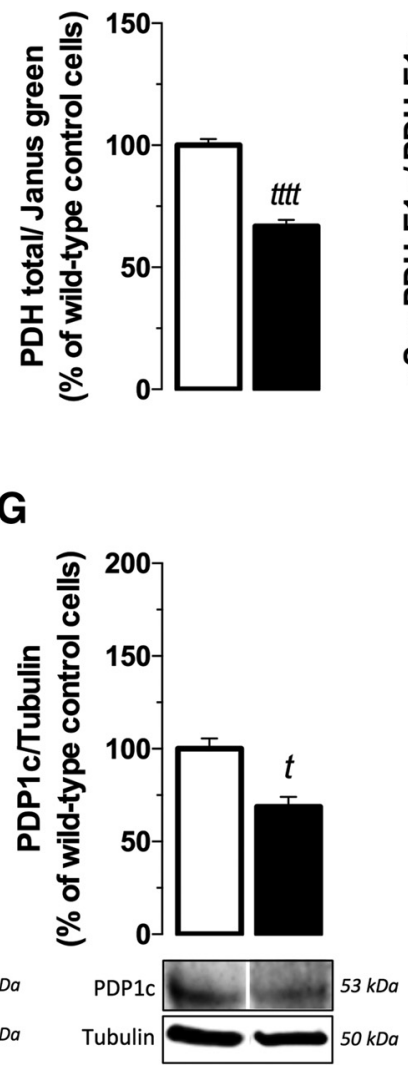

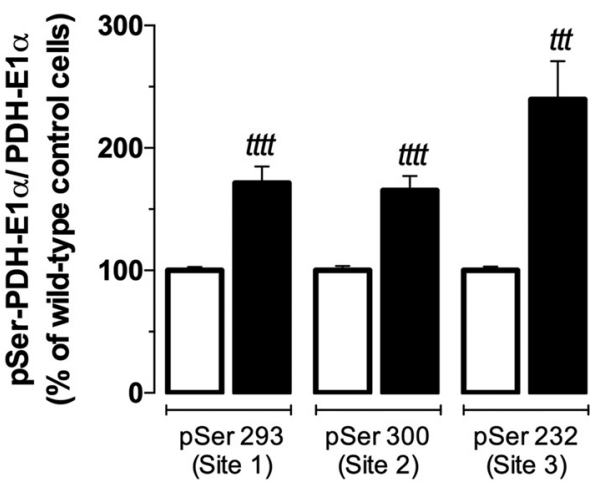

$S T H d h^{Q 7 / Q 7}$ $\mathrm{STH} d h^{\mathrm{Q} 111 / \mathrm{Q} 111}$

Figure 1. Deregulation of $\mathrm{NAD}^{+} / \mathrm{NADH}$ ratio and PDH activity, E1alpha subunit expression, and phosphorylation in cells expressing mutant huntingtin (STHdh $\left.{ }^{\mathrm{Q} 111 / 0111}\right)$. NAD ${ }^{+} / \mathrm{NADH}$ ratio $(\boldsymbol{A})$ and PDH activity $(\boldsymbol{B})$ were measured in total extracts of wild-type and mutant cells. Total PDHE1alpha protein levels ( $\boldsymbol{C}$ ) and phosphorylation at regulatory serines 293 (site 1), 300 (site 2), or 232 (site 3) $(\boldsymbol{D})$ were assessed using the phospho-PDH in cell ELISA kit. Protein levels of PDK1 (E), PDK3 (F), and PDP1C (G) in wild-type and mutant cells were determined by Western blotting. Data are shown as the mean $\pm \mathrm{SEM}$ of total NAD ${ }^{+} / \mathrm{NADH}$ ratio (in pmol/mg protein), total PDH activity (in slope/mg protein), PDH E1alpha/Janus green, phosphorylated form/total PDH E1alpha. Where mentioned, the average value obtained for wild-type was considered $100 \%$. Absolute values for wild-type controls were $1178.00 \pm 247.00 \mathrm{AU} / \mathrm{min} / \mathrm{mg} \mathrm{protein}(\boldsymbol{B}), 3.60 \pm 0.98(\boldsymbol{C}), 3.94 \pm 1.16$ for pSer293, $3.28 \pm 0.62$ for pSer300, and $4.32 \pm 1.42$ for pSer232 (D). Statistical analysis was performed by Student's $t$ test; ${ }^{t} p<0.05$, ${ }^{t t t} p<0.001$, and ${ }^{t t t t} p<0.0001$ compared with the respective wild-type/control cells.

extracts) or $10 \mathrm{ng}$ (for tissue extracts) of template was performed with an initial cycle of $30 \mathrm{~s}$ at $95.0^{\circ} \mathrm{C}$, followed by 40 cycles of $5 \mathrm{~s}$ at $95^{\circ} \mathrm{C}$ plus $5 \mathrm{~s}$ at $63^{\circ} \mathrm{C}$ (for cell extracts) or $61^{\circ} \mathrm{C}$ (for tissue extracts). At the end of each cycle, Eva green fluorescence was recorded to enable determination of Cq. After amplification, melting temperature of the PCR products were determined by performing melting curves, with $0.5^{\circ} \mathrm{C}$ increments every $5 \mathrm{~s}$, from $65^{\circ} \mathrm{C}$ to $95^{\circ} \mathrm{C}$, with fluorescence recording after each temperature increment. For each set of primers, amplification efficiency was assessed and no template and no transcriptase controls were run. For cell extracts, relative normalized expression was determined with CFX96 Manager software (version 3.0; Bio-Rad), using TATA-binding protein (TBP) as the reference gene. Normalization was also performed for the reference gene hypoxanthine guanine phosphoribosyl transferase (Hprt; accession number NM_013556.2), with similar results. For tissue extracts, beta-actin (NM_007393.3), POLR2F (NM_027231.1), GAPDH (NM_008084.2), and Hprt (NM_013556.2) were tested as reference genes, but none of these genes was stable in YAC128 mice treated with SB. Therefore, normalizations were performed in relation to wild-type mice treated with saline.

\section{Statistical analysis}

Results are expressed as mean \pm SEM of the number of independent experiments indicated in the figure legends. Comparisons between multiple groups were performed with two-way or one-way ANOVA, followed by Bonferroni post hoc test, for comparison between experimental groups. Comparison between two groups was performed with the Student's $t$ test (GraphPad Prism Version 6.0, RRID: SCR:002798). The $F$ test was performed to determine the interaction term. Significance was accepted at $p<0.05$.

\section{Results}

PDH dysfunction in cells expressing mutant huntingtin

Mitochondrial bioenergetics has been described to be altered in HD (Cunha-Oliveira et al., 2012). PDC is a central mitochondrial enzyme complex in cellular bioenergetics, linking glycolysis to the TCA cycle and oxidative phosphorylation (Harris et al., 2002; Patel and Korotchkina, 2006). PDC activity can be modulated by phosphorylation (Kolobova et al., 2001) and deregulation of PDC activity and phosphorylation was previously shown by us in HD human cybrids, together with decreased mitochondrial NADH/total NAD ratio (Ferreira et al., 2011).

Using HD mutant mouse striatal cells, we observed an increase in mitochondrial $\mathrm{NAD}^{+} / \mathrm{NADH}$ levels by 2.3 -fold $(p<$ 0.001; Fig. 1A), suggesting a dysfunction in cellular dehydrogenases. We also assessed PDH activity by following the production of $\mathrm{NADH}$ that accompanies the irreversible conversion of pyruvate into acetyl-CoA; a decrease in $\mathrm{PDH}$ activity by $\sim 30 \%(p<$ $0.0001)$ was observed in mutant cells, compared with wild-type striatal cells (Fig. $1 B$ ), which may explain the substantial increase in pyruvate levels detected in mutant cells (Naia et al., 2016a). The protein levels of the E1alpha subunit of PDH, along with its 
A

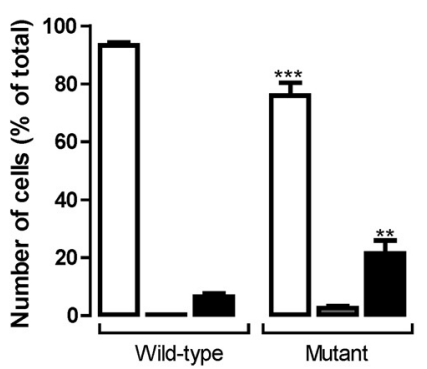

B

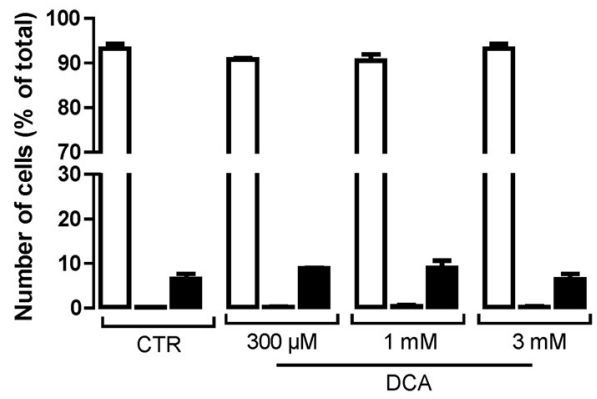

D

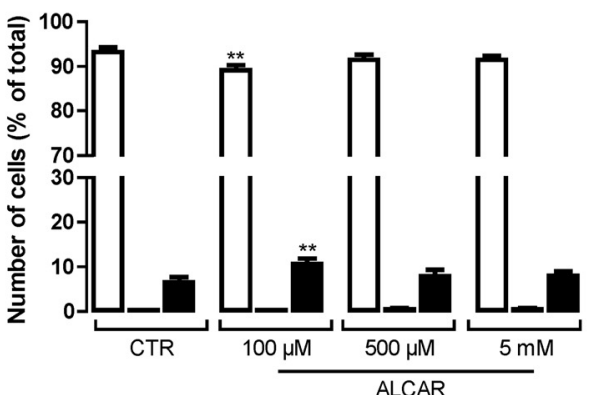

$\mathbf{F}$
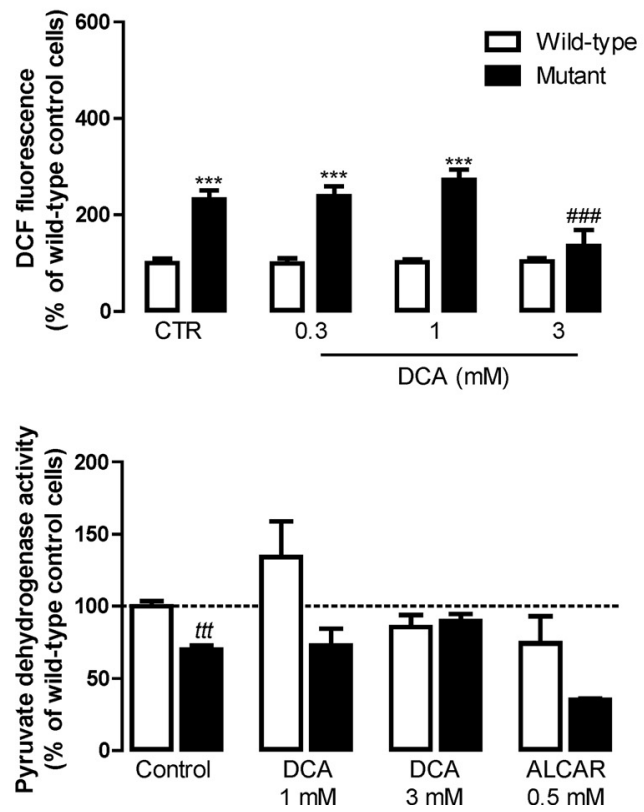

\section{Wild-type}
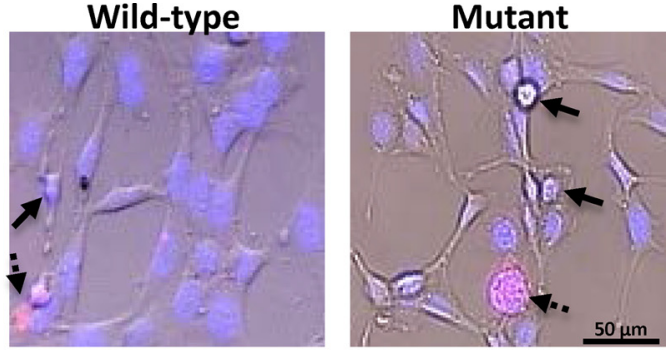

Mutant cells

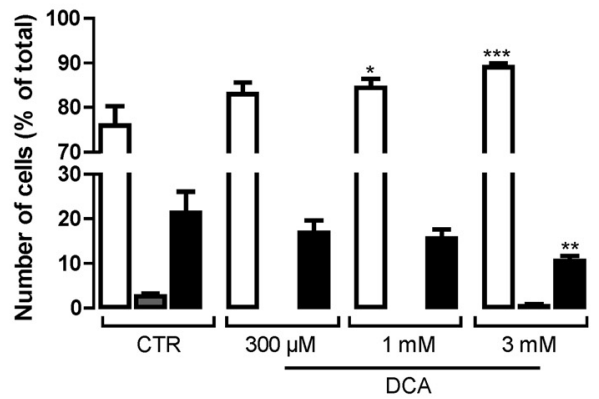

$\mathbf{E}$
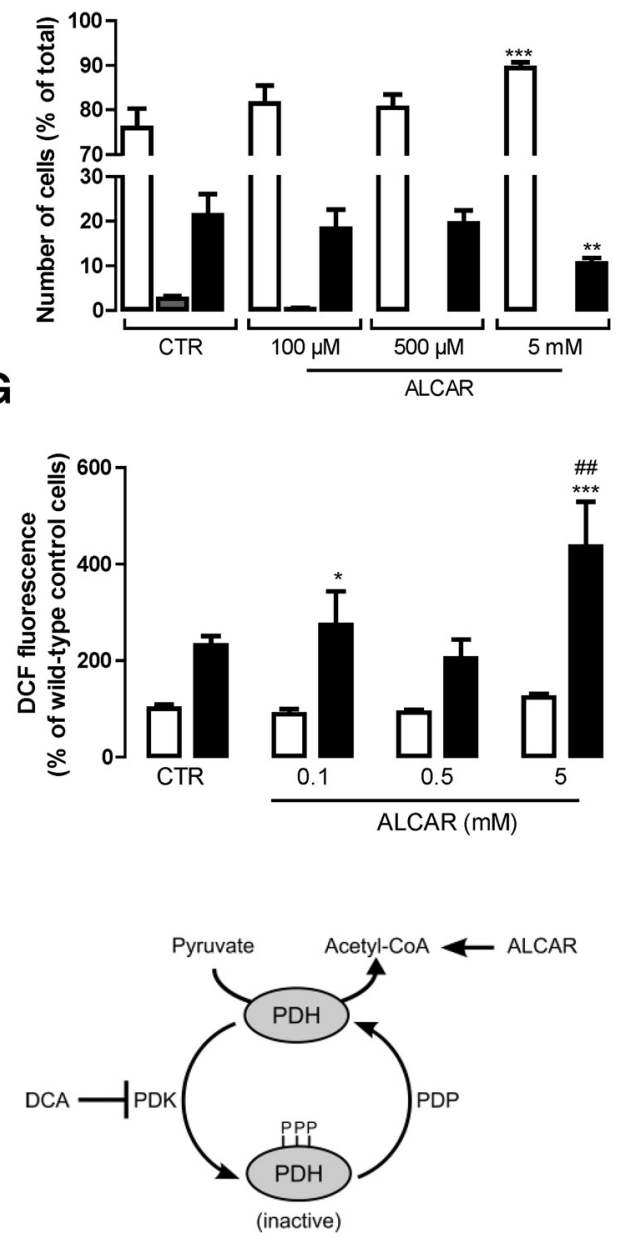

Figure 2. Protective effect of PDH modulators in striatal mutant cells. Cell viability $(\boldsymbol{A}-\boldsymbol{E})$ and redox signaling $(\boldsymbol{F}, \boldsymbol{G})$ of wild-type and mutant cells was analyzed $24 \mathrm{~h}$ after incubation with different concentrations of the PDH activator DCA $(0.3-3 \mathrm{~mm})$ or the acetyl-coenzyme A donor ALCAR $(0.1-5 \mathrm{~mm})$. The effects of these compounds were assessed on PDH activity $(\boldsymbol{H})$ and their mechanisms of action are represented in $\boldsymbol{I}$. $\boldsymbol{A}-\boldsymbol{E}$, To analyze cell viability, cells were stained with fluorescent Hoechst 33342 (blue) and propidium iodide (red) dyes and visualized (Figure legend continues.) 
phosphorylation at three regulatory sites [Ser293 (site 1), Ser300 (site 2), or Ser232 (site 3)], were assessed using a kit based on an immunocytochemistry protocol (Fig. $1 C, D$ ). The total protein levels of the PDH Elalpha subunit (Fig. 1C) were decreased by $\sim 33 \%(p<0.0001)$ in mutant cells compared with wild-type cells. In mutant striatal cells, all three regulatory serines exhibited pronouncedly high phosphorylation levels (Fig. 1D). In Ser232, the increase reached 2.4-fold ( $p<0.001$ ) compared with wildtype cells. This serine corresponds to the regulatory site 3 of $\mathrm{PDH}$ and is phosphorylated by PDK1, which activity seems to be mainly regulated by gene expression (Patel and Korotchkina, 2006). Consistent with increased Ser 232 phosphorylation, PDK1 protein levels were found to be increased by $54 \%(p<0.05)$ in mutant cells (Fig. 1E). In addition, we analyzed the protein levels of PDK3 and the catalytic subunit of the PDH phosphatase PDP1, PDP1c (Fig. 1F, G), described to be the most abundant forms of PDK and PDP, respectively, in the brain (Kolobova et al., 2001; Patel and Korotchkina, 2006). Consistent with the phosphorylation levels of the PDH E1alpha subunit, we detected an increase by $\sim 39 \%$ in PDK3 protein levels $(p<0.05$; Fig. $1 F)$, whereas PDP1c protein levels decreased by $\sim 30 \%(p<0.05$; Fig. $1 G)$ in mutant striatal cells.

\section{PDH activation rescues cell viability and ROS production in mutant cells}

HD is characterized by a large number of cellular abnormalities, including an increase in ROS production (Ribeiro et al., 2012, 2014) that may lead to protein and lipid oxidation and ultimately to a decrease in cell viability (Sorolla et al., 2010).

We assessed the viability of wild-type and mutant cells by fluorescence microscopy. Mutant cells presented lower cell viability ( $\sim 76 \%$ viable cells) compared with wild-type cells ( $\sim 93 \%$ viable cells). Accordingly, the number of apoptotic mutant cells increased by 3.25 -fold ( $p<0.01$ ) compared with the wild-type cell line (Fig. 2A).

To assess the role of PDH dysfunction in cell viability, cells were treated with DCA or ALCAR for $24 \mathrm{~h}$ before the experiments. DCA is a PDK inhibitor shown previously to increase PDH activity and decrease Elalpha subunit turnover (Fouque et al., 2003), whereas ALCAR allows overpassing the PDH impairment by translocating through the inner mitochondrial membrane, being converted into acetyl-CoA by carnitine acyltransferases and thus directly "feeding" the TCA cycle (Jones et al., 2010; Fig. 2I). DCA (0.3-3 mм) or

\footnotetext{
$\leftarrow$

(Figure legend continued.) by fluorescence microscopy as in the images shown in $\boldsymbol{A}$ to evaluate the nuclear morphology (DNA condensation and fragmentation) to assess apoptotic cell death (full arrows) and plasma membrane integrity to assess the number of necrotic cells (dashed arrows). Cell viability, necrosis, and apoptosis were expressed as a percentage of the total number of cells. In $\boldsymbol{A}-\boldsymbol{E}$, statistical analysis was performed by one-way ANOVA. $\boldsymbol{F}, \boldsymbol{G}$, To analyze altered redox signaling, cells were loaded with $\mathrm{DCFH}_{2}-\mathrm{DA}(20 \mu \mathrm{m})$ for $30 \mathrm{~min} 24 \mathrm{~h}$ after exposure to DCA or ALCAR and the fluorescence of DCF ( $480 \mathrm{~nm}$ excitation, $550 \mathrm{~nm}$ emission) resulting from the probe oxidation was followed continuously for $1 \mathrm{~h}$ at $33^{\circ} \mathrm{C}$ and corrected for total protein. Results are expressed as mean \pm SEM of three experiments performed in triplicate or quadruplicate. The wild-type control (CTR) $100 \%$ of DCF fluorescence was $3.67 \times 10^{6} \pm$ $0.7 \times 10^{6} \mathrm{RFU} / \mathrm{min} / \mathrm{mg}$ protein. In $\boldsymbol{F}$ and $\boldsymbol{G}$, statistical analysis was performed by two-way ANOVA, followed by Bonferroni post test, and revealed a significant interaction between genotype and treatment in $\boldsymbol{F}\left(F_{(3,38)}=6.161, p<0.0016\right)$ and a significant effect of ALCAR treatment in $\boldsymbol{G}\left(F_{(3,40)}=3.558, p<0.0225\right)$. $\boldsymbol{H}$, PDH activity was measured by spectrophotometry. Results are expressed as mean \pm SEM of three independent experiments (performed in triplicate) and wild-type values (100\%) correspond to $1178.00 \pm 247.00 \mathrm{AU} / \mathrm{min} / \mathrm{mg}$ protein. Statistical significance: ${ }^{*} p<0.05$ or ${ }^{* * *} p<0.001$ compared with the respective wild-type condition and ${ }^{\# \#} p<0.01$ or $^{\# \#} p<0.001$ compared with control (untreated) condition. For $\boldsymbol{H}$, ${ }^{t t t} p<0.001$ by the Student's $t$ test.
}

ALCAR ( 0.5 and $5 \mathrm{~mm}$ ) did not affect the viability of wild-type cells significantly (Fig. $2 B, D$ ). At $100 \mu \mathrm{M}$, ALCAR had slight toxic effects in wild-type cells, decreasing cell viability by $\sim 4 \%(p<0.01$; Fig. $2 D)$. In mutant cells, DCA (0.3-1 mM) and ALCAR (0.1-0.5 mM) did not affect cell viability (Fig. 2C,E). Interestingly, the higher concentrations of both compounds, $3 \mathrm{~mm}$ DCA and $5 \mathrm{~mm}$ ALCAR, similarly increased mutant cell viability by decreasing the percentage of apoptotic cells by $\sim 11 \%(p<0.01$; Fig. $2 C, E)$.

Our group has shown recently that ROS levels increase in striatal mutant cells (Ribeiro et al., 2012, 2014). Indeed, mutant cells showed a great capacity of oxidizing $\mathrm{DCFH}_{2}$ to DCF (by $\sim 2.3$-fold, $p<0.001$; Fig. $2 F, G$ ), a fluorescent redox probe that can be oxidized by peroxynitrite $\left(\mathrm{ONOO}^{-}\right)$and resulting $\mathrm{ROS}$ such as hydroxyl radicals ( $\left.{ }^{\circ} \mathrm{OH}\right)$ and intracellular iron signaling (Kalyanaraman et al., 2012). ALCAR at the highest concentration ( $5 \mathrm{mM}$ ) enhanced DCF fluorescence in mutant cells, by $\sim 2$-fold $(p<0.01)$ over basal conditions (Fig. $2 G$ ). Conversely, $3 \mathrm{~mm}$ DCA completely prevented the increase in DCF fluorescence in mutant cells (Fig. 2F).

To determine whether DCA or ALCAR affected PDH activity in our model, we incubated the cells for $24 \mathrm{~h}$ with these compounds (Fig. $2 \mathrm{H})$. ALCAR (0.5 mM) showed a tendency to decrease $\mathrm{PDH}$ activity, probably due to $\mathrm{PDH}$ end product inhibition by high levels of acetyl-CoA. This effect, associated with increased ROS levels, highly compromises the beneficial effects of ALCAR in these cells. Nevertheless, incubation with $3 \mathrm{~mm}$ DCA almost completely recovered $\mathrm{PDH}$ activity in mutant cells, suggesting a high correlation of increased PDH activity, decreased ROS levels, and increased cell viability.

\section{HDACIs rescue cell viability and mitochondrial function in mutant cells}

HDACIs were shown previously to prevent cell death (Beal and Ferrante, 2004) and ameliorate mitochondrial $\mathrm{Ca}^{2+}$ handling (Oliveira et al., 2006) in HD models. Therefore, we evaluated the protective effect of HDACIs in mutant and wild-type cells incubated for $24 \mathrm{~h}$ with 10, 50, and $100 \mathrm{~nm}$ TSA (a pan-lysine deacetylase inhibitor) and 100, 250, and $500 \mu \mathrm{M}$ PB or SB (which act preferentially on HDAC classes I and IIa). Cells were labeled with Hoechst and PI fluorescent dyes to analyze the nuclear morphology and to evaluate apoptotic and necrotic cell death (Fig. 3). Exposure to $\mathrm{PB}$ or SB did not affect the number of necrotic or apoptotic wild-type cells at any of the concentrations tested (Fig. $3 C, E)$. However, TSA exhibited toxic effects in wild-type cells (Fig. 3A). At $10 \mathrm{~nm}$, TSA induced a decrease by $\sim 3 \%(p<0.05)$ in viable cells and, at $100 \mathrm{nM}$, this HDACI induced a decrease by $\sim 7 \%(p<0.001)$ in viable cells, accompanied by an increase of $\sim 6 \%(p<0.001)$ in apoptotic wild-type cells (Fig. 3A). Converesely, in mutant cells, cell viability was recovered in the presence of the HDACIs (Fig. $3 B, D, F$ ). All concentrations of $\mathrm{PB}$ and $\mathrm{SB}$ tested induced a significant increase in the percentage of viable mutant cells (between $8.7 \%$ and $14.5 \%$ for $\mathrm{PB}$ and $13.9 \%$ and $16.1 \%$ for $\mathrm{SB}$ ), together with a decrease in apoptotic cells (between $8.8 \%$ and $12.3 \%$ for PB and $10.4 \%$ and $13.9 \%$ for SB) (Fig. $3 D, F)$. TSA showed protective effects over mutant cell viability at the lowest concentration tested $(10 \mathrm{nM})$ only, increasing the number of viable cells by $\sim 12 \%(p<0.05$; Fig. $3 B)$

To assess whether recovery of cell viability in the presence of the HDACIs was accompanied by improvement in mitochondrial function, we tested the effect of the most promising compounds, $\mathrm{SB}$ and $\mathrm{PB}$, on mitochondrial respiration and adenine nucleotide levels (Fig. 4). Mutant cells exhibited a decrease in mitochondrial respiration under basal conditions (by $\sim 44 \%$, 
A

Wild-type cells

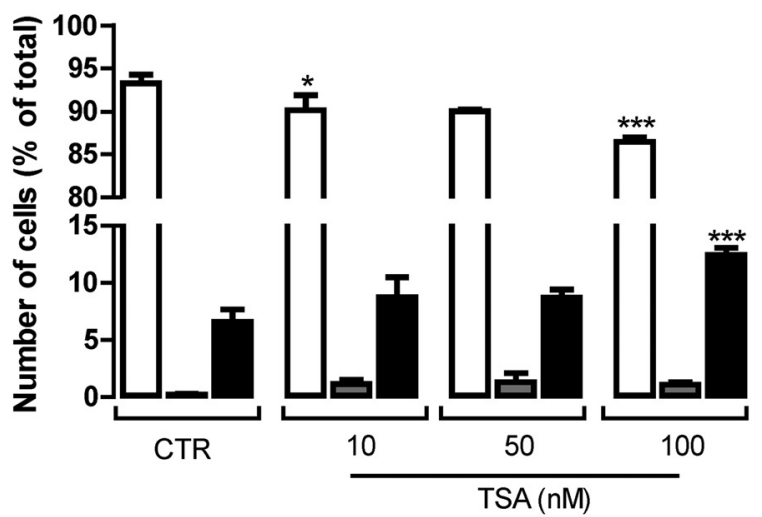

C

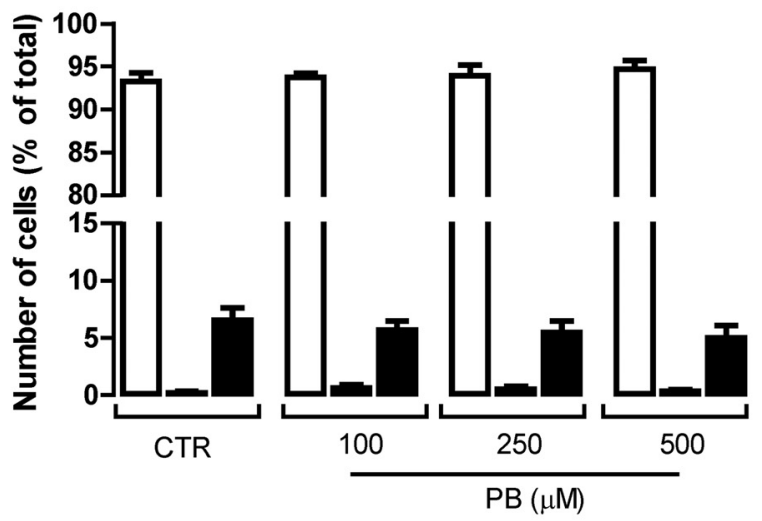

E

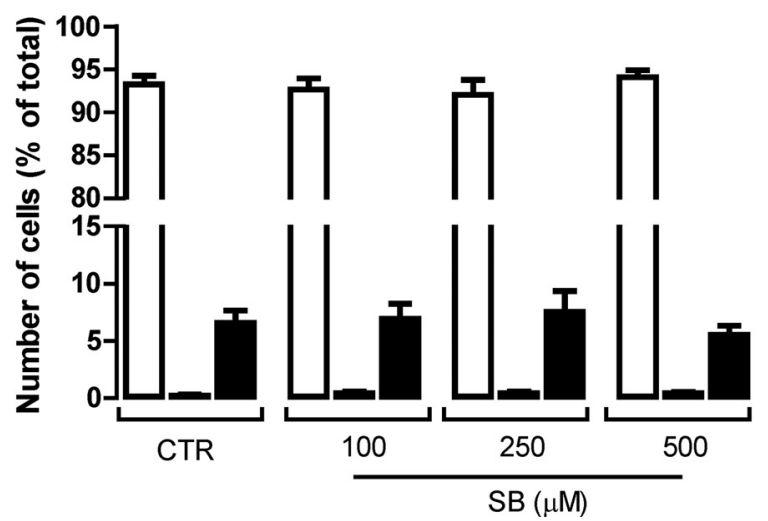

B

Mutant cells

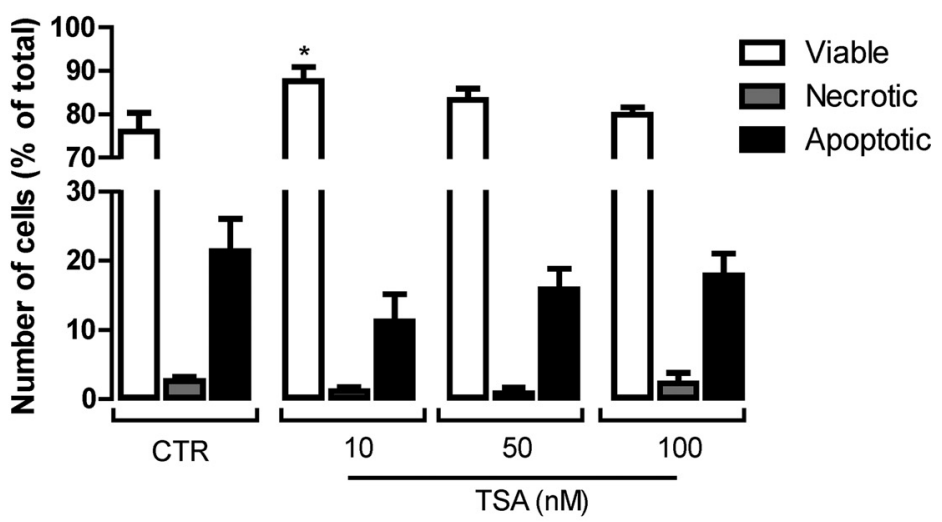

D

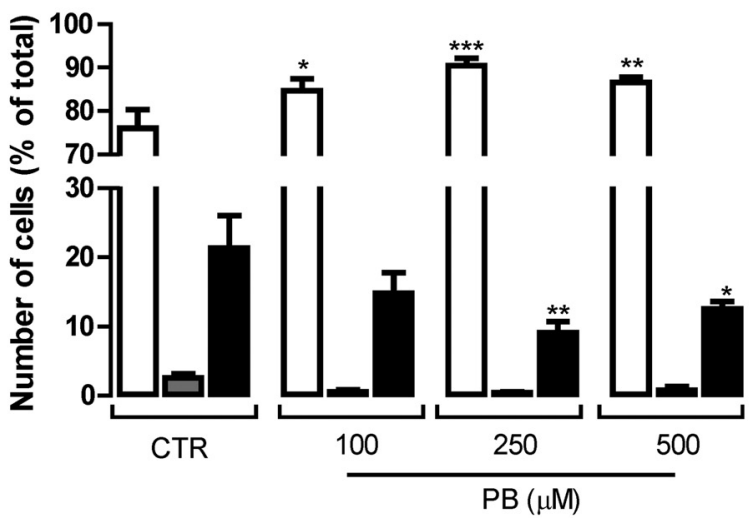

$F$

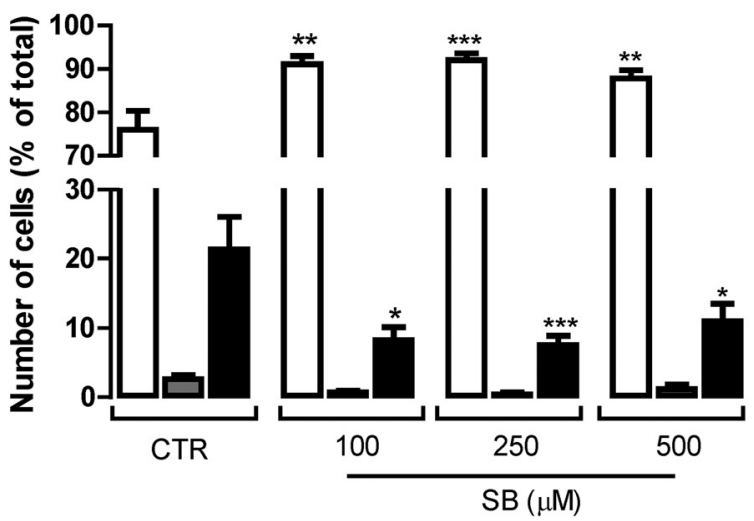

Figure 3. Protective effect of HDACls on mutant cell viability. After $24 \mathrm{~h}$ of incubation with TSA $(10-100 \mathrm{~nm}), \mathrm{PB}(100-500 \mu \mathrm{m})$, and SB (100 - 500 $\mu \mathrm{m})$, wild-type $(\boldsymbol{A}, \boldsymbol{C}, \boldsymbol{E})$ and mutant $(\boldsymbol{B}, \boldsymbol{D}, \boldsymbol{F})$ cells were stained with Hoechst and PI fluorescent dyes to evaluate apoptotic cell death by following the nuclear morphology (DNA condensation and fragmentation) and plasma membrane integrity (to assess the number of necrotic cells) by fluorescence microscopy, as detailed in Figure 2 . Results are expressed as the mean \pm SEM of three independent experiments (performed in quadruplicate). Statistical analysis was performed by one-way ANOVA, followed by Bonferroni post test: ${ }^{*} p<0.05,{ }^{* *} p<0.01$, and ${ }^{* * *} p<0.001$ compared with the respective control.

$p<0.01$; Fig. $4 A$ ) and the difference was still observed in the presence of the uncoupler FCCP (by $\sim 50 \%, p<0.05$ ), although FCCP enhanced $\mathrm{O}_{2}$ consumption by $\sim 2$-fold (Fig. $4 B$ ). Mutant cells also presented lower ATP (by $\sim 20 \%, p<0.05$ ), ADP (by $\sim 45 \%, p<0.001$ ), and AMP (by $\sim 60 \%, p<0.05$ ) levels compared with wild-type cells (Fig. $4 C-E)$. In the presence of PB (250 $\mu \mathrm{M})$ and $\mathrm{SB}(500 \mu \mathrm{M})$, the respiratory activity of mutant cells recovered to nearly the levels observed in wild-type cells (Fig. $4 A, B)$. Treatment with $\mathrm{SB}(500 \mu \mathrm{M})$ also restored intracellular ATP levels in mutant cells (Fig. 4C). Remarkably, DCA (3 mM) improved mitochondrial respiration in mutant cells (Fig. 4A,B), which may be associated with its effect on PDH activity (Fig. $2 H$ ).

To evaluate the changes in acetylation of nuclear targets by HDACIs, we analyzed histone 3 (H3) acetylation in wild-type and mutant cells by Western blotting (Fig. 5). Mutant cells showed a tendency for a slight decrease in $\mathrm{H} 3$ acetylation (data not shown), as described previously (Oliveira et al., 2006). TSA (at $100 \mathrm{~nm}$ ) significantly increased $\mathrm{H} 3$ acetylation in both wild-type (by $\sim 2.3$-fold, $p<0.01$; Fig. 5A) and mutant cells (by $\sim 2.1$-fold, $p<$ 0.05 ; Fig. $5 B$ ). At nontoxic concentrations (10 and $50 \mathrm{~nm}$ ), TSA 
A

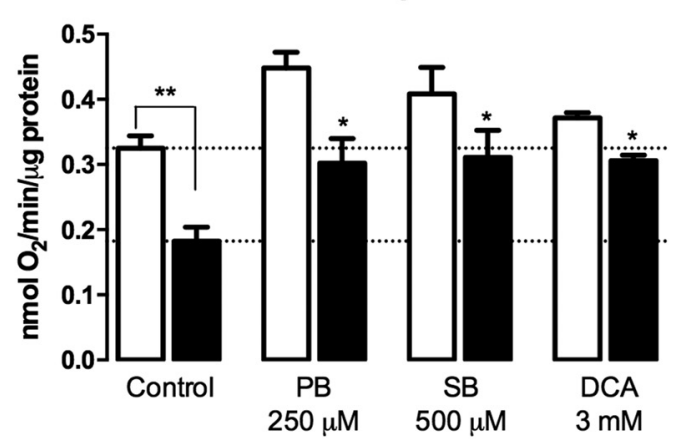

B

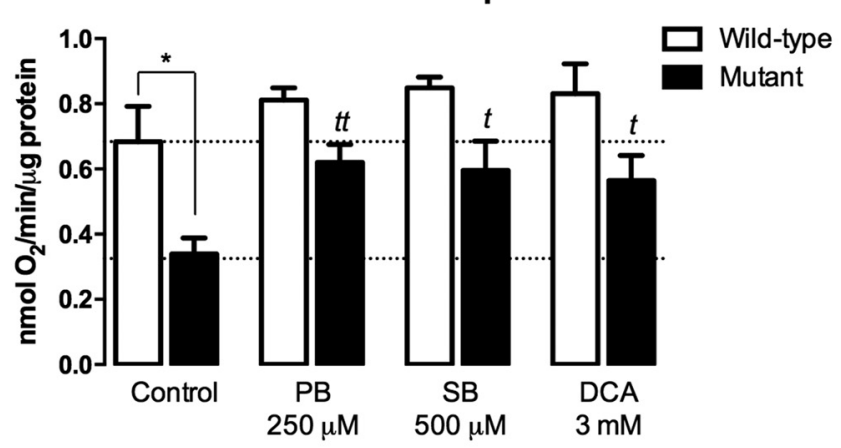

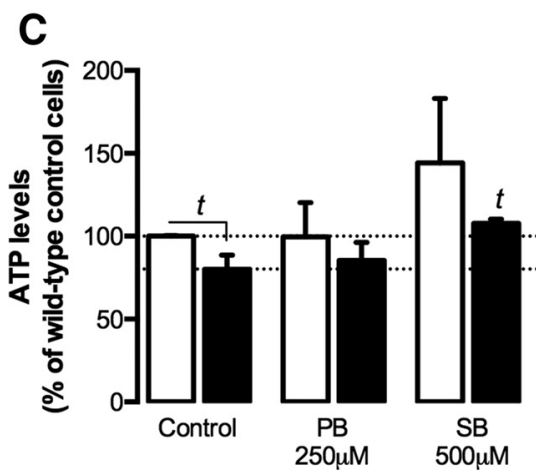

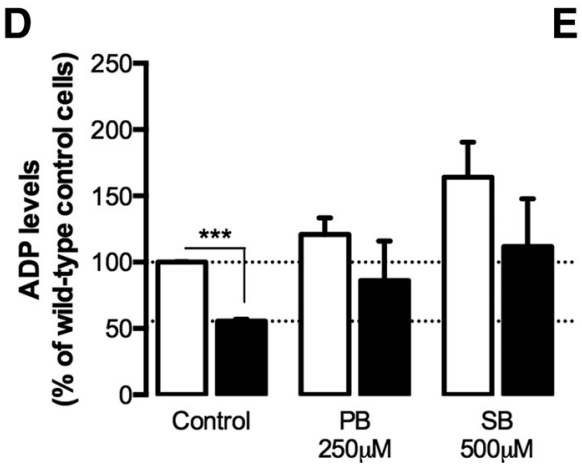

E

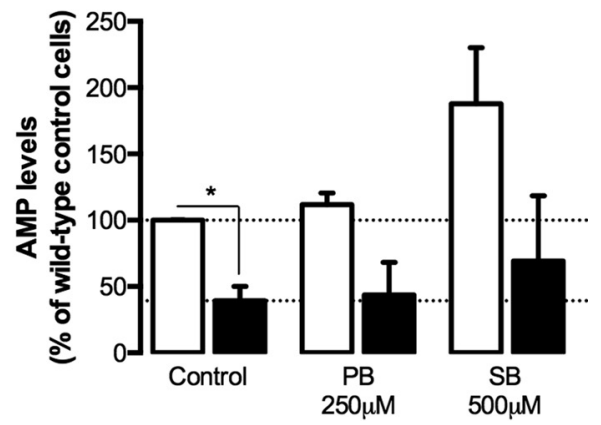

Figure 4. Protective effect of HDACls on mitochondrial function in $\mathrm{HD}$ striatal cells. Oxygen consumption by wild-type and mutant cells was measured in an $\mathrm{O}_{2}$ Clark electrode, after $24 \mathrm{~h}$ of incubation with PB $(250 \mu \mathrm{M}), S B(500 \mu \mathrm{M})$, and DCA $(3 \mathrm{~mm})$ before $(\boldsymbol{A})$ and after $(\boldsymbol{B})$ sequential addition of oligomycin $(2.5 \mu \mathrm{g} / \mathrm{ml})$ and FCCP $(2.5 \mu \mathrm{m})$ and compared with untreated controls. Dotted lines in $\boldsymbol{A}$ represent average control basal values for wild-type and mutant cells and dotted lines in $\boldsymbol{B}$ represent control FCCP-stimulated respiration of wild-type and mutant cells. $\mathbf{C}-\boldsymbol{E}$, Energy metabolism in wild-type and mutant cells was evaluated by measurement of ATP $(\boldsymbol{C}), A D P(D)$, and AMP $(\boldsymbol{E})$ levels by high-performance liquid chromatography after $24 \mathrm{~h}$ of incubation with PB and SB. Results are expressed as mean \pm SEM of $4-5$ independent experiments. Statistical analysis was performed by two-way ANOVA, followed by Bonferroni post hoc test. A significant effect of the treatment was found in $\mathrm{A}\left[F_{(3,28)}=9.102, p=0.0002\right], \mathrm{B}\left[F_{(3,28)}=4.291, p=0.0134\right]$ and $\mathrm{D}\left[F_{(2,15)}=4.024, p=0.0399\right]$, with ${ }^{*} p<0.05,{ }^{* *} p<0.01$, ${ }^{* * *} p<0.001$ compared with the respective control. ${ }^{t} p<0.05,{ }^{t t} p<0.01$, compared with the respective control, by the Student's $t$ test.

showed a tendency for an increase in $\mathrm{H} 3$ acetylation in wild-type and mutant cells, which was not statistically significant. PB (Fig. $5 C, D$ ) and $\mathrm{SB}$ (Fig. 5E,F) showed a higher effect at $500 \mu \mathrm{M}$, increasing $\mathrm{H} 3$ acetylation by $\sim 1.6$-fold $(p<0.001)$ and $\sim 2.1$ fold $(p<0.01)$, respectively, in wild-type cells and by 1.4 -fold $(p<0.01)$ and 1.3 -fold $(p<0.01)$, respectively, in mutant cells. At $250 \mu \mathrm{M}, \mathrm{PB}$ and SB also showed a nonsignificant tendency for increased $\mathrm{H} 3$ acetylation in mutant cells by $\sim 1.4$-fold and 1.3-fold, respectively. Although these results show a positive correlation between $\mathrm{H} 3$ acetylation and viability, lower doses of HDACIs that decreased apoptosis in mutant cells did not always increase $\mathrm{H} 3$ acetylation, suggesting that the beneficial effects of HDACIs may be much broader than the simple regulation of a specific histone. Consistent with this, the three HDACI tested were previously shown to regulate core histones $\mathrm{H} 2 \mathrm{~A}, \mathrm{H} 2 \mathrm{~B}$, and H4 (Schölz et al., 2015).

HDACIs rescue PDH dysfunction in mutant cells

To determine whether the protective effects achieved by HDACIs on mitochondrial function and viability could reflect a recovery of PDH function, we next evaluated the effect of HDACIs on the protein (Fig. 6A,C) and phosphorylation (Fig. 6B,D) levels of the PDH E1 alpha subunit. TSA at $100 \mathrm{~nm}$ was not used due to the decrease in cell viability in wild-type cells and the lack of significant protection in mutant cells. In wild-type cells, $10 \mathrm{~nm}$ TSA and $500 \mu \mathrm{M}$ PB increased the protein levels of Elalpha subunit by 1.4 -fold and 1.5-fold ( $p<0.05$ ), respectively (Fig. 6A). In addi- tion, $250 \mu \mathrm{M}$ PB and $500 \mu \mathrm{M}$ SB increased E1alpha PDH subunit levels in mutant cells by 1.3 -fold and 1.4 -fold $(p<0.001)$, respectively (Fig. 6C).

In wild-type cells, $250 \mu \mathrm{M} \mathrm{PB}$ decreased the phosphorylation of PDH E1alpha at serine 232 by $\sim 33 \%$ ( $p<0.01$; Fig. $6 B$ ). Furthermore, $500 \mu \mathrm{M}$ PB significantly decreased PDH E1alpha phosphorylation at all serines by $\sim 31 \%(p<0.05)$ for Ser293, $22.5 \%(p<0.01)$ for Ser300, and 44.5\% $(p<0.001)$ for Ser 232 (Fig. 6B). SB (at $500 \mu \mathrm{M}$ ) also significantly decreased PDH Elalpha phosphorylation at Ser293 and Ser232 $(p<0.05)$ in wild-type cells (Fig. $6 B$ ). In mutant cells, phosphorylation at Ser293 (site 1) decreased by $\sim 33.6 \%(p<0.01)$ in the presence of $250 \mu \mathrm{M}$ PB (Fig. 6D). Importantly, in mutant cells, $500 \mu \mathrm{M} \mathrm{SB}$ was the most efficient condition by decreasing the phosphorylation at all three serines, reducing the phosphorylation of Ser293 by $\sim 41.6 \%(p<0.01)$, Ser300 by $46.5 \%$ ( $p<0.05)$, and Ser 232 by $29.4 \%(p<0.05)$ (Fig. $6 D)$, in good agreement with the positive results obtained in mitochondrial function (Fig. 4). In contrast, $10 \mathrm{~nm}$ TSA increased Ser232 phosphorylation in these cells $(p<$ 0.05; Fig. 6D), suggesting its inefficacy in rescuing HD-related PDH dysfunction.

Rescuing of PDH-related mitochondrial dysfunction by SB is associated with decreased gene expression of PDKs

As described previously, inactivation of PDH by phosphorylation is catalyzed by one of four PDK isoforms. Apart from the four PDKs, there are two isoforms of PDPs (PDP1 and PDP2) present 
A
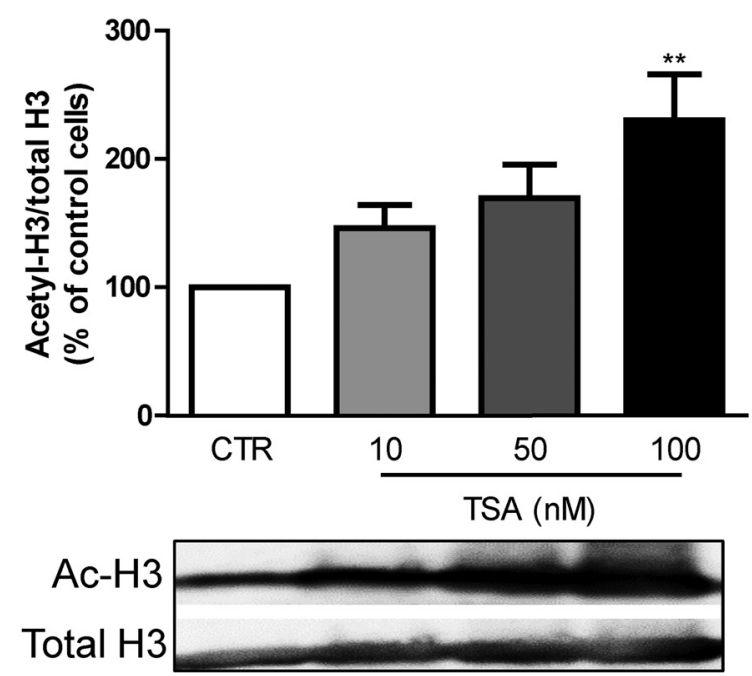

C
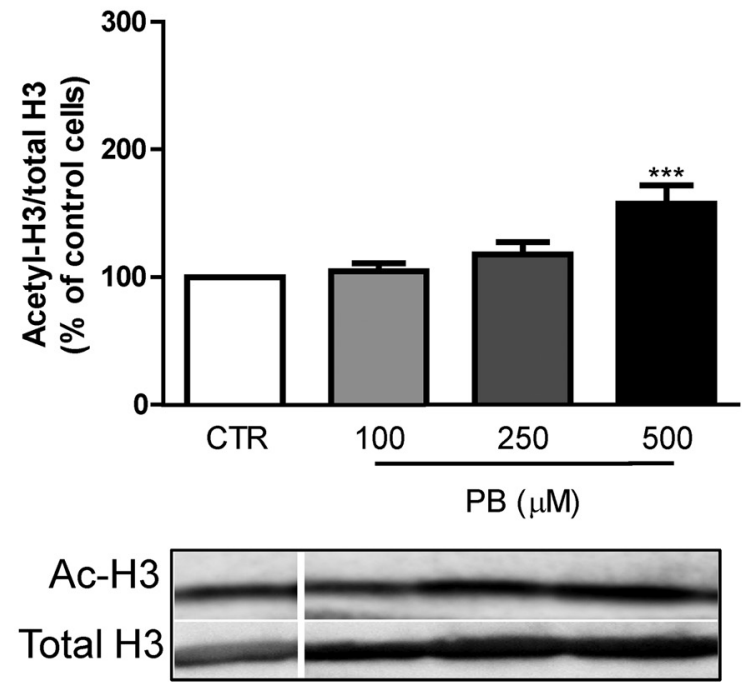

E
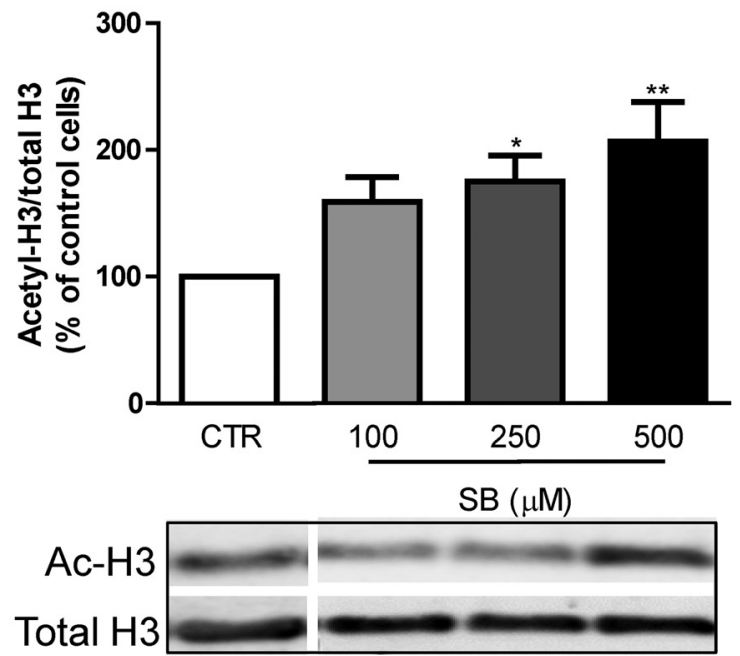

B
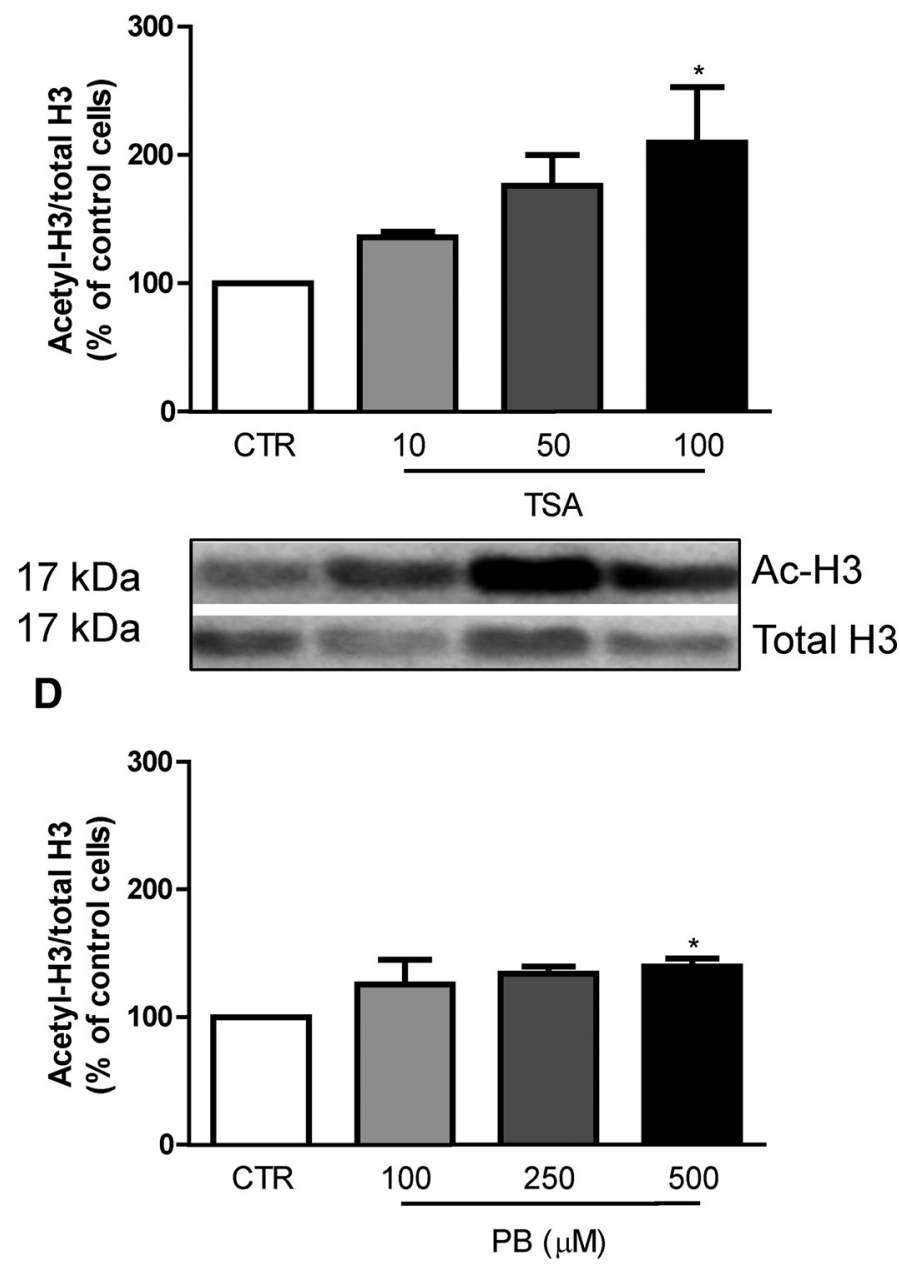

$17 \mathrm{kDa}$
$17 \mathrm{kDa}$

F

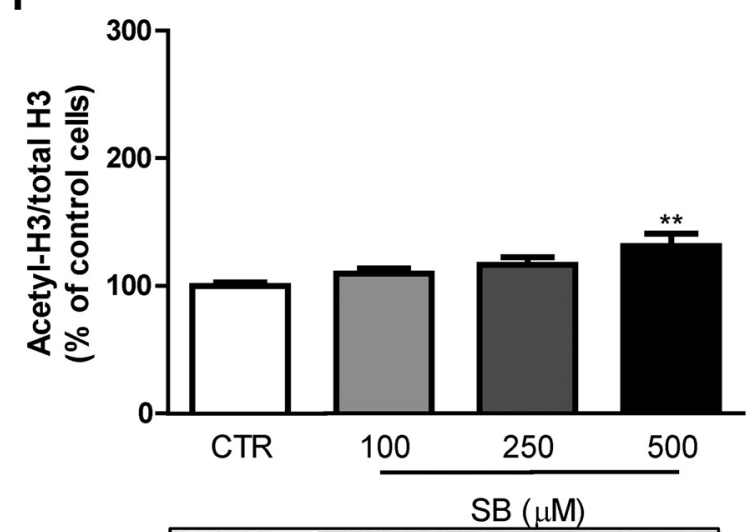

$17 \mathrm{kDa}$ $17 \mathrm{kDa}$
$\mathrm{Ac}-\mathrm{H} 3$ Total H3

Figure 5. Effectiveness of $\mathrm{HDACl}$ in increasing the acetylation of histone $\mathrm{H} 3$ in wild-type and mutant cells. Wild-type and mutant cells were incubated for $24 \mathrm{~h}$ with different concentrations of the HDACI TSA (10-100 nм; $\boldsymbol{A}, \boldsymbol{B}), \mathrm{PB}(100-500 \mu \mathrm{m} ; \boldsymbol{C}, \boldsymbol{D})$ and SB $(100-500 \mu \mathrm{m} ; \boldsymbol{E}, \boldsymbol{F})$ and total extracts and Western blots were obtained as described in Material and Methods. Results are expressed as mean \pm SEM of five to eight independent experiments. Statistical analysis was performed by one-way ANOVA followed by Bonferroni $p o s t$ hoc test: ${ }^{*} p<0.05$, ${ }^{* *} p<0.01$, and ${ }^{* * *} p<0.001$ compared with the respective control. 


\section{A}

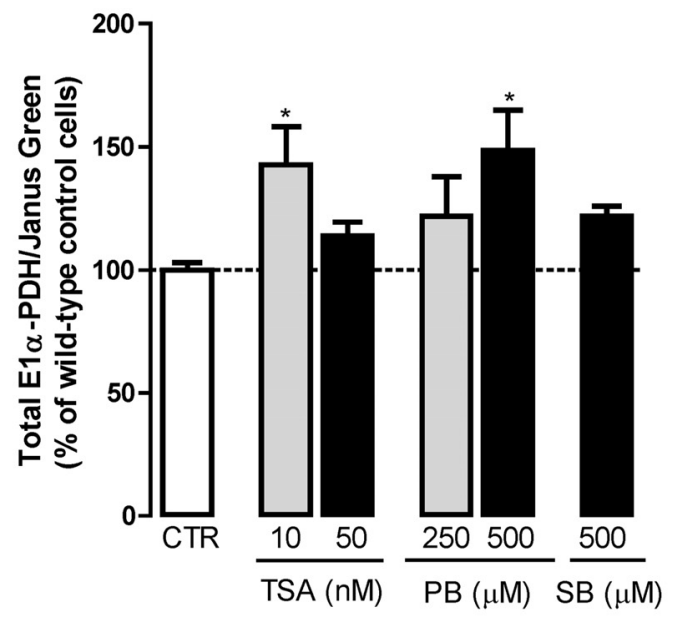

C

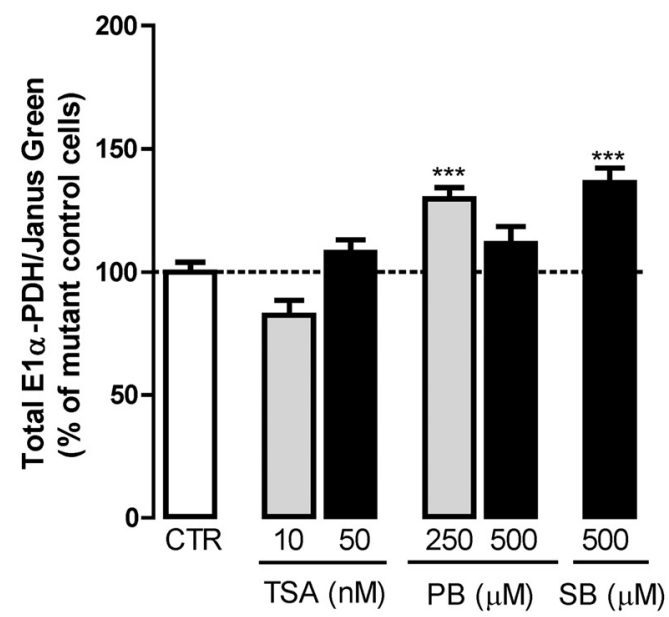

B

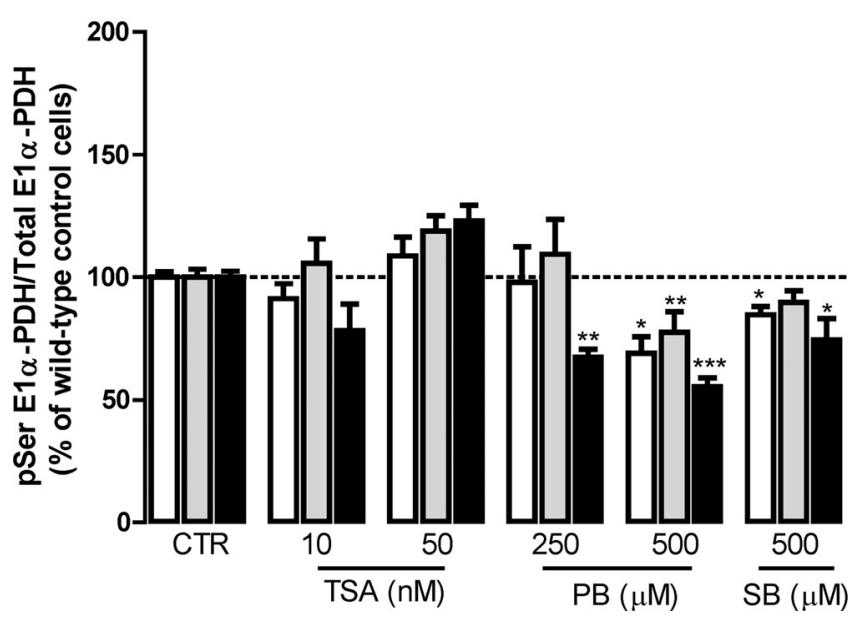

D

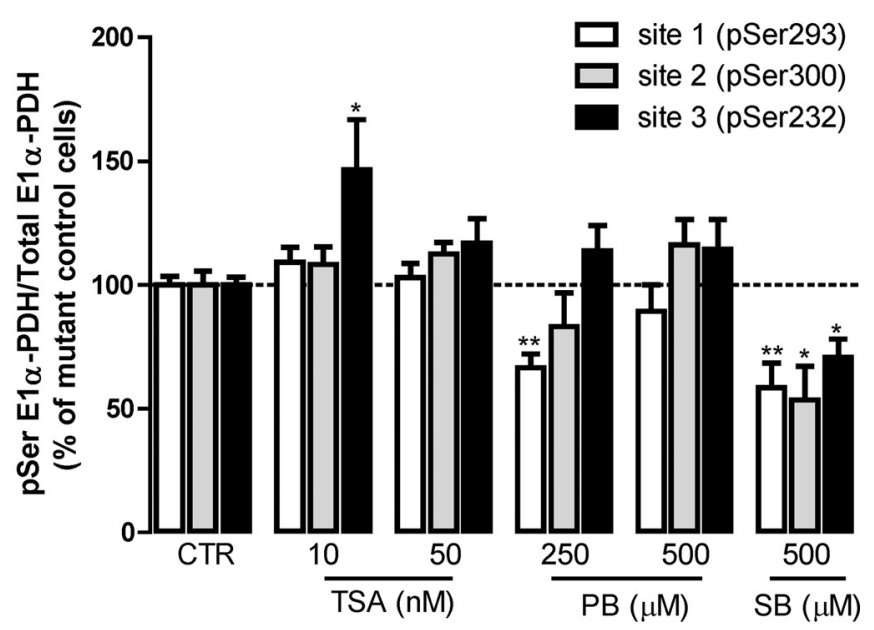

Figure 6. Effect of HDACls on PDH E1alpha protein levels and phosphorylation in mutant striatal cells. Wild-type $(\boldsymbol{A}, \boldsymbol{B})$ and mutant $(\boldsymbol{C}, \boldsymbol{D})$ striatal cells were incubated for $24 \mathrm{~h}$ with different concentrations of HDACl, TSA (10 and $50 \mathrm{~nm}), \mathrm{PB}(250$ and $500 \mu \mathrm{m})$, and SB $(500 \mu \mathrm{m})$ and the levels of expression $(\boldsymbol{A}, \boldsymbol{C})$ and phosphorylation $(\boldsymbol{B}, \boldsymbol{D})$ of PDH subunit E1alpha were assessed using phospho-PDH in the cell ELISA kit. Results are expressed as mean \pm SEM of three to five independent experiments (performed in duplicates or triplicates). For each graph, the wild-type (100\%) values were $1.96 \pm 0.96$ for PDH E1 alpha $(\boldsymbol{A}), 4.67 \pm 1.33$ for pSer293, $3.31 \pm 1.12$ for pSer300, and $7.99 \pm 2.33$ for pSer232 (B). The mutant control (100\%) values correspond to $6.01 \pm 1.93$ for PDHE1alpha (C),3.34 \pm 2.32 for pSer293, $2.00 \pm 1.35$ for pSer300, and $2.85 \pm 0.93$ for pSer232 (D). Statistical analysis was performed by one-way ANOVA, followed by Bonferroni post hoc test: ${ }^{*} p<0.05,{ }^{* *} p<0.01$, and ${ }^{* * *} p<0.001$ compared with wild-type cells.

in mammalian cells (Karpova et al., 2003; Rardin et al., 2009). Because $500 \mu \mathrm{M}$ SB decreased PDH phosphorylation in mutant cells in all serine residues tested, we assessed the effect of this compound on mRNA expression of each of its regulatory kinases and phosphatases, namely PDK1-4 and PDP1-2, respectively, and the expression of PDHA1, the gene that encodes the PDH E1 alpha subunit, in wild-type and mutant cells (Fig. 7). Consistent with what was described previously in the brain (Bowker-Kinley et al., 1998; Patel and Korotchkina, 2006), PDK2 and PDK3 were the most abundant PDK isoforms, whereas PDK1 exhibited low expression and PDK4 mRNA was almost negligible in wild-type and mutant mouse striatal cells; as for the phosphatases, PDP1 was $\sim 8$-fold more abundant than PDP2 in both striatal cell lines (Fig. 7A). Therefore, untreated mutant cells presented no significant changes in the mRNA levels of PDHA1 or any of the regulatory kinases or phosphatases.

Consistently with mRNA data (Fig. 7C,E), SB $(500 \mu \mathrm{M})$ did not affect PDK1 or PDP1 protein levels (data not shown). However, exposure to SB $(500 \mu \mathrm{M})$ induced a decrease in the expression of PDK2 by $\sim 39 \%(p<0.01)$ and $24.5 \%(p<0.05)$ in wild-type and mutant cells, respectively (Fig. 7F). This was accompanied by a decrease in the expression of PDK3 by $\sim 26.5 \%$ $(p<0.05)$ and $19.6 \%(p<0.05)$ in wild-type and mutant cells, respectively (Fig. $7 G$ ), suggesting that the decrease in the $\mathrm{PDH}$ E1alpha phosphorylation observed in the presence of SB may be associated with decreased transcription of PDK2 and PDK3.

To confirm this hypothesis, we also looked into transcription factors that control the upregulation of PDKs. Elevated mitochondrial-derived ROS, as observed in STHdh $h^{\mathrm{Q} 11 / \mathrm{Q} 111}$ cells (Ribeiro et al., 2013), have been implicated in the activation and stabilization of HIF- $1 \alpha$, an important component of the oxygensensing pathway that has been largely described as a suppressor of metabolism and mitochondrial oxygen consumption ( $\mathrm{Pa}$ pandreou et al., 2006) by directly trans-activating the genes encoding for PDK1 (Kim et al., 2006), as well as PDK2 and PDK3 (Lu et al., 2008; Prigione et al., 2014). In striatal cells preincubated at different time points with SB $(500 \mu \mathrm{M})$, we induced hypoxia for $1 \mathrm{~h}$ to allow HIF-1 $\alpha$ stabilization/accumulation because at normal $\mathrm{O}_{2} / \mathrm{ROS}$ levels, it is rapidly degraded by the proteasome (Chandel et al., 1998; Movafagh et al., 2015). At control 
A

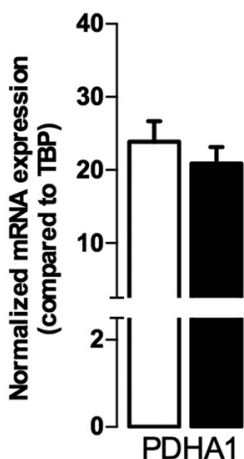

B

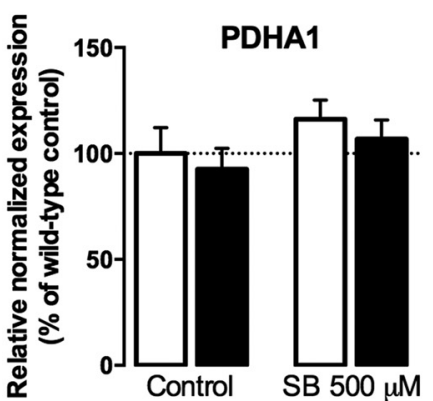

E

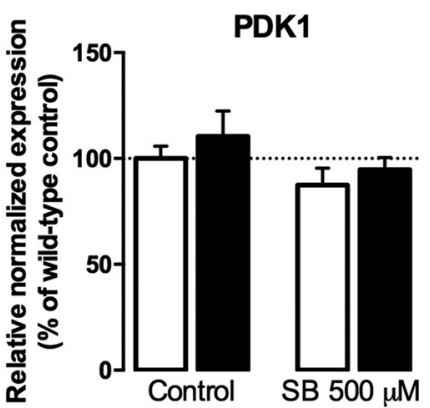

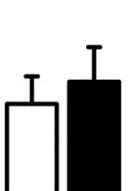
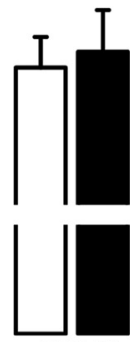

PDK3

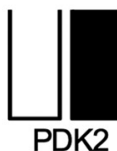

Wild-type

Mutant
C

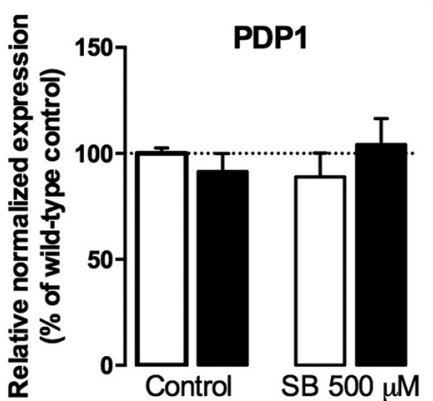

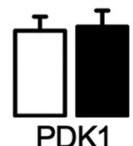

$\mathbf{F}$

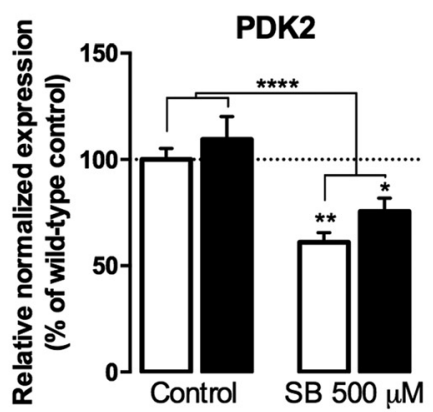

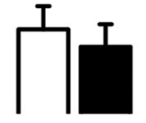
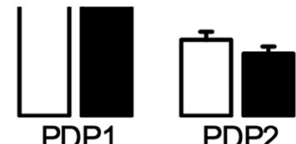

D

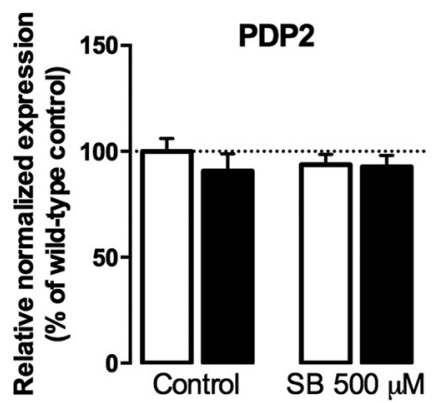

H

I
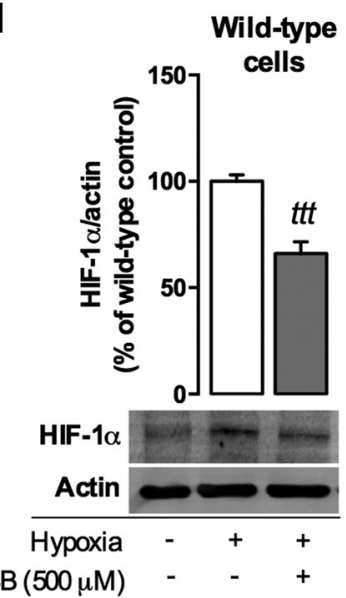$$
S B(500 \mu M)--1-1
$$

G

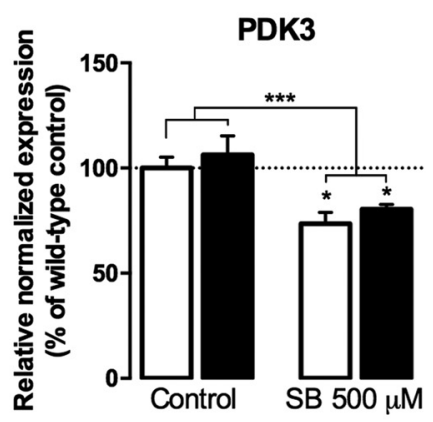

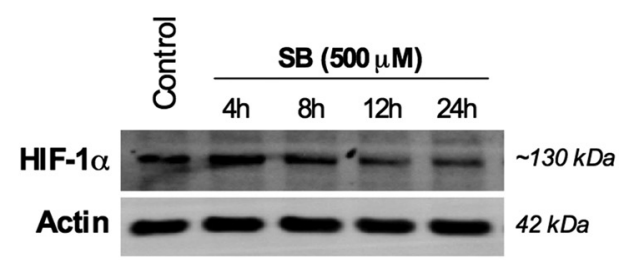

Figure 7. Effect of SB on mRNA expression of PDH-related genes and associated HIF-1 $\alpha$ transcription factor in HD knock-in striatal cells. Cells were incubated in the absence or presence of 500 $\mu \mathrm{M}$ SB for $24 \mathrm{~h}$ and total RNA was extracted, converted into CDNA, and amplified by $q R T-P C R$, as described in the Materials and Methods. Gene expression was normalized to the reference gene TBP $(\boldsymbol{A}-\boldsymbol{G})$. $\boldsymbol{A}$, Comparison of mRNA expression levels of PDHA1, PDKs, and PDPs in wild-type and mutant cells. $\boldsymbol{B}-\boldsymbol{G}$, Effect of SB on PDHA1 (B), PDP1 (C), PDP2 (D), PDK1 (E), PDK2 (F), and PDK3 (G). In $\boldsymbol{H}$ and $\boldsymbol{I}$, striatal cells were submitted to hypoxia for $1 \mathrm{~h}$ after SB treatment at different time points $(\boldsymbol{H})$ or for $24 \mathrm{~h}(\boldsymbol{I})$. Protein levels of HIF- $1 \alpha$ in wild-type and mutant cells were determined by Western blotting. Results are the mean \pm SEM of four to five independent experiments performed in duplicate (for qRT-PCR experiments). Statistical analysis by two-way ANOVA revealed a strong significant effect of SB treatment in $\boldsymbol{F}\left(F_{(1,25)}=27.31, p<0.0001\right)$ and $\boldsymbol{G}\left(F_{(1,22)}=19.68, p=0.0002\right) ;{ }^{*} p<0.05$ compared with the respective control. No significant interaction was found between genotype and treatment. In $I,{ }^{t t} p<0.01,{ }^{t t} p<0.001$ compared with the mutant or wild-type control, respectively, by Student's $t$ test. 
A

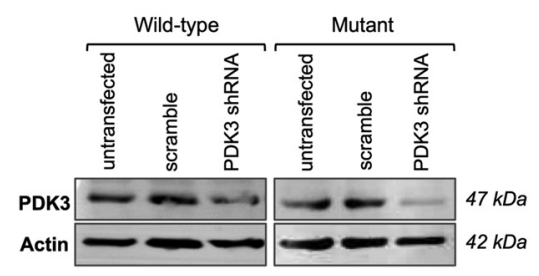

B

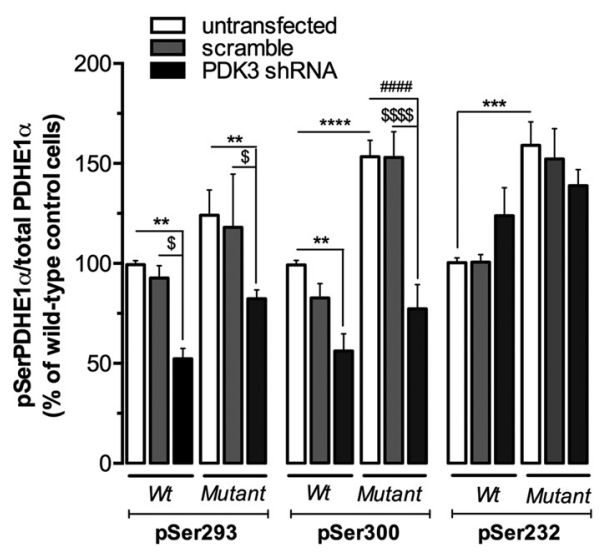

C Wild-type cells
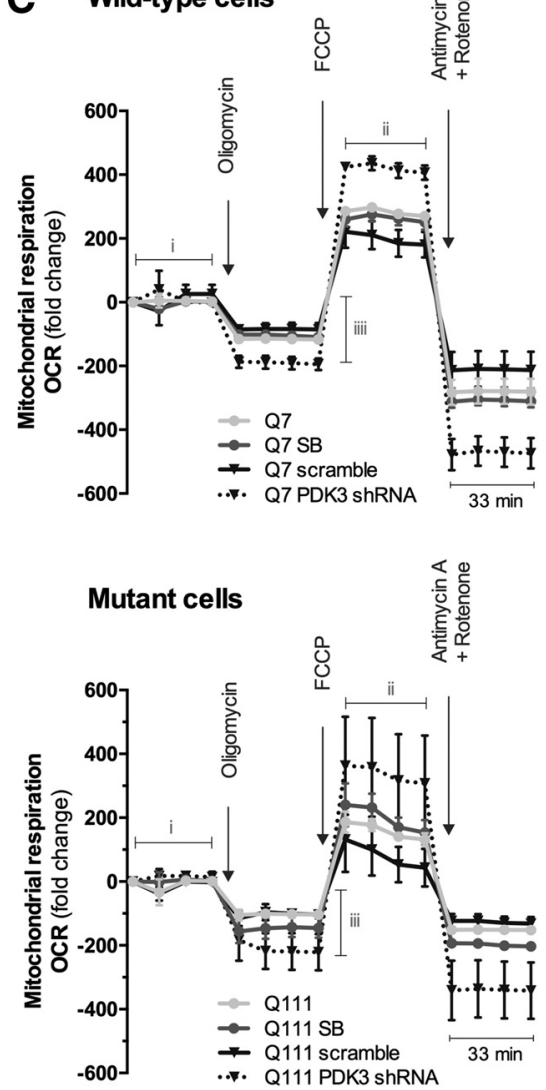

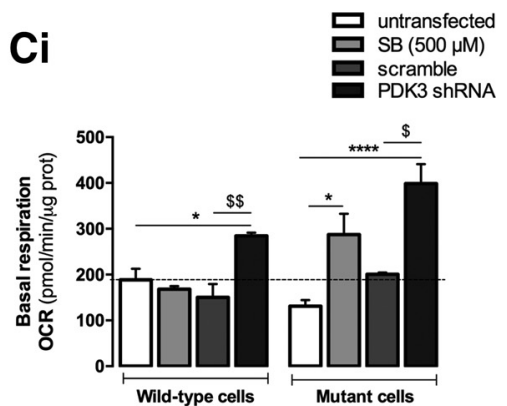

Cii

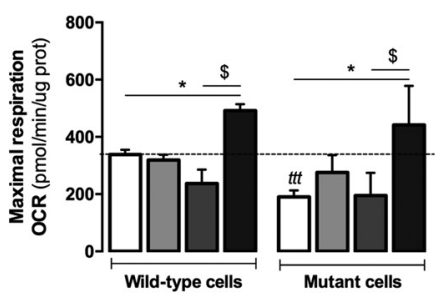

Ciii

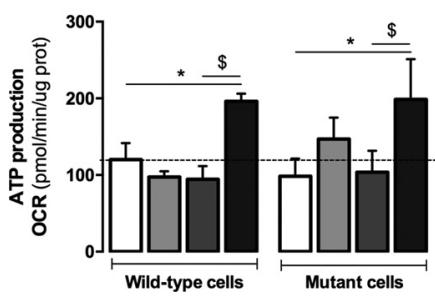

Figure 8. PDK3 KD decreases PDH phosphorylation and improves mitochondrial respiration. Striatal cells were transfected with plko.1-shRNA against PDK3 or plk0.1-scramble vector $48 \mathrm{~h}$ before the experiments or incubated for $24 \mathrm{~h}$ with $500 \mu \mathrm{m}$ SB. The efficacy of the KD was confirmed by Western blotting probed for PDK3 $(\boldsymbol{A})$ and by decreased PDH E1alpha subunit phosphorylation at Ser293 and Ser300 (B). Statistical analysis was performed by two-way ANOVA and a significant interaction between genotype and PDK3KD was found $\left(F_{(2,40)}=3.675, p=0.0343\right)$. In addition, PDK3KD had a significant effect on Ser293 $\left(F_{(2,40)}=7.693, p=0.0015\right)$ and Ser300 $\left(F_{(2,40)}=27.62, p<0.0001\right)$ phosphorylation. The $0 C R$ was measured with a Seahorse Bioscience XF24 flux analyzer (C). Basal mitochondrial respiration is represented in $\left(i\right.$ and exhibits a significant interaction between genotype and treatment $\left(F_{(3,25)}=3.248, p=0.0387\right)$. A strong, significant effect of treatment on basal respiration was also observed $\left(F_{(3,25)}=12.57, p<0.0001\right)$. Striatal cells were treated for the indicated times with $1 \mu \mathrm{m}$ oligomycin $\mathrm{A}, 0.9 \mu \mathrm{m} F C C P$, and $1 \mu \mathrm{m}$ antimycin $\mathrm{A}$ plus $1 \mu \mathrm{m}$ rotenone to determine the proportion of oxygen consumption due to ATP turnover (Ciii) and maximal rate of respiration (Cii). PDK3KD or SB treatment had a significant effect on both Cii $\left(F_{(3,26)}=4.817, p=0.0085\right)$ and $C$ iii $\left(F_{(3,26)}=4.436, p=0.0120\right)$. Results are expressed as mean \pm SEM of three to four independent experiments. Statistical significance: ${ }^{*} p<0.05{ }^{* *} p<$

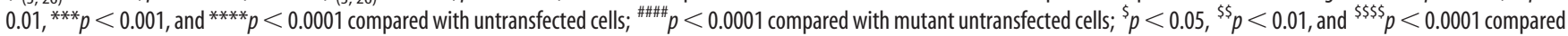
with plko.1-transfected cells by two-way ANOVA followed by Bonferroni post test; ${ }^{t t t} p<0.001$ compared with the wild-type (Wt) control (in Cii) by Student's $t$ test.

conditions or in cells treated with SB for 4 or $8 \mathrm{~h}$, oxygen depletion benefited HIF- $1 \alpha$ accumulation (Fig. $7 H$ ). However, after $24 \mathrm{~h}$ of SB incubation, a significant decrease in HIF- $1 \alpha$ levels was observed in both wild-type $(p<0.001)$ and mutant cells $(p<$ 0.01 ; Fig. 7 H, I). Similar results were obtained with TSA (100 nM; data not shown), suggesting an effect primarily mediated by HDACIs activity. HIF- $1 \alpha$ acetylation was shown to enhance its ubiquitination (Jeong et al., 2002; Kong et al., 2006), corroborating the hypothesis that HDACIs may be critical for HIF- $1 \alpha$ proteasomal degradation and consequent PDK2 and PDK3 transcriptional inhibition. The forkhead box O1 (FoxO1) also regulates PDK gene expression (Jeong et al., 2012) and acetylation attenuates its transcriptional activity (Daitoku et al., 2011); however, no changes in acetyl-FoxO1 levels were observed in either wild-type or mutant cells treated with SB (data not shown). Therefore, we showed that SB treatment could reduce PDH Elalpha phosphorylation/inactivation through decreased HIF-1 $\alpha$ and related PDK2 and PDK3 expression.

To further link PDK inhibition with improved mitochondrial function (observed in Fig. 4), we knocked down (KD) PDK3 because this enzyme can incorporate almost $50 \%$ more phos- phate than PDK2 (Kolobova et al., 2001). The KD was confirmed by the $50 \%$ and $79 \%$ reduction of PDK3 protein levels in wildtype and mutant cells, respectively (Fig. 8A). PDK3 KD significantly reduced PDH Elalpha phosphorylation at Ser293 (by $\sim 47.4 \%$ and $47.7 \%$ in wild-type and mutant cells, respectively) and Ser300 (by $\sim 43.7 \%$ and $49.6 \%$ in wild-type and mutant cells, respectively) (Fig. 8B). PDH E1alpha phosphorylation at Ser232 (site 3) was not changed significantly because it is phosphorylated by PDK1 (Kolobova et al., 2001). Mitochondrial function was evaluated by the OCR using the Seahorse Bioscience XF24 flux analyzer. We measured basal respiratory capacity, oligomycinsensitive respiration coupled to ATP synthesis, and maximal respiration in the presence of FCCP (Fig. $8 C$ ). At the end of the experiment, striatal cells were treated with a combination of rotenone and antimycin A to assess nonmitochondrial respiration. Although the decrease in basal respiration in mutant cells was not statistically significant, maximal respiratory capacity was significantly reduced by $\sim 43.7 \%(p<0.001)$ in these cells. Exposure to $\mathrm{SB}(500 \mu \mathrm{M})$ increased basal respiration by $\sim 2.2$-fold $(p<0.05)$ and ATP production by $\sim 1.5$-fold (Fig. $8 \mathrm{Ci}$,Ciii) and almost recovered maximal respiration in mutant cells (Fig. 8Cii), corrob- 
orating the previous results (Fig. $4 A, B$ ). Remarkably, PDK3 KD increased by 1.5 -fold $(p<0.05)$ and 3.0-fold $(p<0.001)$ the basal respiration in wild-type and mutant cells, respectively (Fig. $8 C i)$. Likewise, maximal respiration and ATP production were enhanced after PDK3 KD in both wild-type (by $\sim 1.5$-fold and 1.6-fold, respectively) and mutant cells (2.3-fold and 2.0-fold, respectively) $(p<0.05)$. These results confirmed that reduced PDK3 expression counteracts mitochondrial dysfunction observed in HD mutant cells and that SB treatment may exert its effect through partial suppression of PDK3 expression, as shown in Figure 7.

\section{SB rescues $\mathrm{PDH}$ metabolism and motor balance in HD mice}

To confirm the relevance of these results in an HD animal model, we analyzed phospho-PDH-related metabolism in the cortex of 9-month-old YAC128 and wild-type mice treated with $1 \mathrm{mg} / \mathrm{kg} / \mathrm{d}$ $\mathrm{SB}$ or vehicle solution. In addition, the significance of in vivo PDC activation was validated by behavior studies (Fig. 9). YAC128 mice at 9 months of age were described previously to exhibit motor abnormalities with dysfunctional open-field activity and rotarod performance abnormalities, followed by brain weight loss and evident striatal atrophy (Slow et al., 2003; Van Raamsdonk et al., 2005). In addition, cortical metabolic defects related with decreased sterol levels were described previously at this age (Valenza et al., 2007), suggesting that metabolic alterations in this brain region precede cortical atrophy, which is significant at 12 months of age (Van Raamsdonk et al., 2005). In the present study, YAC128 mouse cortex presented lower levels of acetylated H3, by $\sim 58 \%$ ( $p<0.05)$, compared with wild-type mice. Importantly, SB treatment increased $\mathrm{H} 3$ acetylation in both wild-type $(p<$ $0.01)$ and YAC128 $(p<0.01)$ mice, the latter presenting acetylation levels comparable to those observed in saline-treated wildtype mice (Fig. 9A). Moreover, YAC128 mice presented an increase of $\sim 50 \%(p<0.05)$ in PDH E1 alpha subunit phosphorylated at Ser232 (Fig. 9B) and an increase by $\sim 1.88$-fold $(p<0.0001), 1.80$-fold $(p<0.0001)$, and 3.44 -fold $(p<0.001)$, respectively, in cortical PDK1-3 mRNA levels compared with wild-type mice (Fig. 9C). These mice also showed a tendency for decreased cortical ATP/ADP levels (by $\sim 45 \%, p=0.07$ ) and reduced energy charge (by $\sim 68 \%, p<0.01$ ) (Fig. $9 D, E$ ). SBtreated YAC128 and wild-type animals showed a large reduction in PDK1-3 mRNA levels in the cortex. In wild-type mice cortex, SB treatment induced a reduction in PDK1-3 mRNA levels, respectively, by $\sim 87.7 \%(p<0.001), 85.2 \%(p<0.001)$, and 96.7\% $(p<0.05)$ compared with saline-treated wild-type mice (Fig. 9C). Importantly, in the brain cortex of YAC128 mice, SB treatment induced a reduction in phosphorylated PDH levels (at Ser232) by $\sim 62 \%(p<0.001$; Fig. $9 B)$ and in mRNA levels of PDK1-3, respectively, by $\sim 91.7 \%(p<0.0001), \sim 90.2 \%$ ( $p<$ 0.0001 ), and $\sim 98.4 \%$, respectively $(p<0.0001$; Fig. $9 C)$. The recovery of PDC function by SB normalized both ATP/ADP levels and energy charge (Fig. 9D,E), corroborating the changes observed in SB-treated HD cell line, and regularized YAC128 mice body weight (data not shown), reported to be augmented due to their genetic background (Van Raamsdonk et al., 2006).

Behavior analysis demonstrated that saline-treated YAC128 mice display impaired motor learning; that is, when placed at a constant rotating rod $(5 \mathrm{rpm})$ in the rotarod apparatus, they took twice as long to learn the task compared with saline-treated wildtype mice $(p<0.01$; Fig. $9 F)$. Consistent with this, the accelerated task showed that YAC128 mice not only exhibited deficits in motor learning, because there was no improvement between sequential trials, but also showed lack of balance and coordination with a latency to fall by $40 \%, 38 \%$, and $45 \%$ lower in trials 2,3 , and 4, respectively, compared with wild-type mice ( $p=0.0003$; Fig. $9 G$ ). After SB treatment, YAC128 mice showed an improvement in motor learning in fixed-speed task, which was corroborated in the accelerated task, in which SB-treated YAC128 mice showed increasing progress of latency to fall throughout the trials $(p=0.0001)$, resembling the values of saline-treated wild-type mice in the two last trials (Fig. 9F,G). The results suggest that both saline-treated wild-type and SB-treated YAC128 mice are more capable of learning, associated with a better motor coordination, in relation to saline-treated YAC128 mice.

\section{Discussion}

The present work shows that full-length mHTT inhibits PDH activity by decreasing the PDH E1 alpha subunit and increasing its phosphorylation at three serine regulatory sites. The positive regulation of these sites is governed by enhanced PDK1 and PDK3 protein levels and reduced PDP1c. Reestablishment of PDH function in HD cells by HDACI and DCA was linked to increased mitochondrial function and decreased ROS and cell death. Treatment with SB efficiently decreased PDH phosphorylation due to reduced mRNA expression of PDKs, in particular PDK3 (the most active and abundant PDK isoform in the brain), in HD striatal cells and YAC128 mouse brain, improving mitochondrial function and bioenergetics and positively influencing motor learning and coordination in YAC128 transgenic mice.

\section{PDH dysfunction in HD models}

In early 1980s, Sorbi et al. (1983) described decreased PDC activity in HD human brain, suggesting a possible role of this enzymatic complex in mitochondrial deficits linked to bioenergetic dysfunction in HD. As shown previously by us, the use of pyruvate instead of glucose as an energetic substrate accentuated the bioenergetic evidences of mitochondrial dysfunction in HD striatal neurons (Oliveira et al., 2006); moreover, metabolically supplementing mitochondria with pyruvate under glycolysis inhibition did not recover ATP levels in HD cybrids, which, together with a decreased mitochondrial NADH/NADt ratio and unaltered activity of mitochondrial complexes I-IV, signalized alterations in mitochondrial function upstream oxidative phosphorylation (Ferreira et al., 2010, 2011). Here, we showed decreased PDH activity in striatal STHdh ${ }^{\mathrm{Q} 111 / \mathrm{Q} 111}$ cells, which may be explained by decreased PDH E1 alpha protein levels and higher phosphorylation at three regulatory serines (293,300, and 232) of E1alpha subunit. Moreover, YAC128 mouse cortex exhibited increased PDH E1alpha phosphorylation at Ser232. Similar findings were described by us in HD cybrids (Ferreira et al., 2011) and in primary YAC128 cortical neurons (Naia et al., 2016a) exhibiting higher phosphorylation of PDH E1alpha at Ser232 and Ser293. This suggested dysfunctional mechanisms responsible for phosphorylation/dephosphorylation of these regulatory sites (Rardin et al., 2009). Indeed, mutant cells showed increased PDK1 and PDK3 protein levels, accompanied by decreased levels of the catalytic subunit of the most abundant $\mathrm{PDH}$ phosphatase, PDP1c. Decreased E1alpha protein levels could be due to alterations in protein expression (Perluigi et al., 2005) in response to modified transcription factors known to regulate PDH, such as PGC-1alpha (Kiilerich et al., 2010), described to be altered in HD models, including STHdh ${ }^{\mathrm{Q} 111 / \mathrm{Q} 111}$ cells (Cui et al., 2006). Nevertheless, expression of PDHA gene, which encodes for PDH Elalpha subunit, was not significantly affected in mutant cells. Similarly, no changes in mRNA levels of PDKs or PDPs were observed in HD cells. Therefore, altered protein turnover and 
A

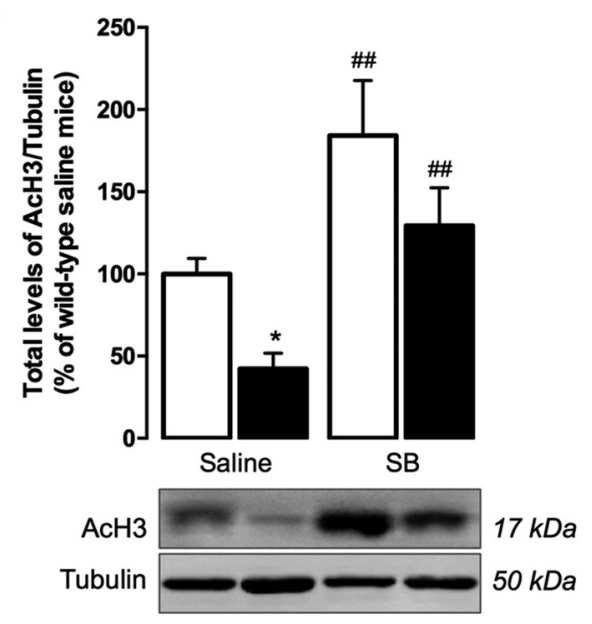

C

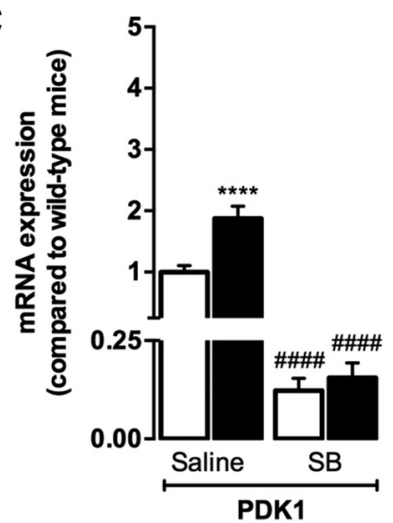

$\mathbf{F}$

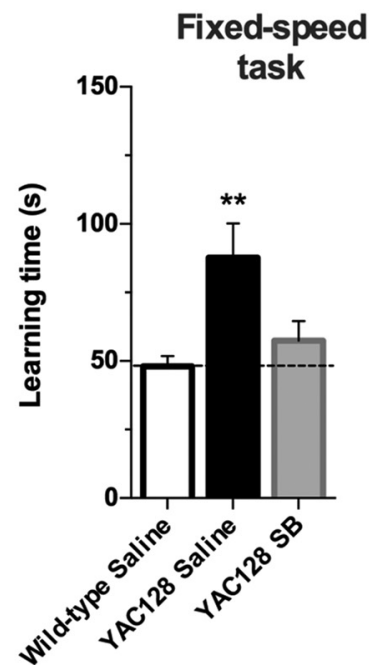

B

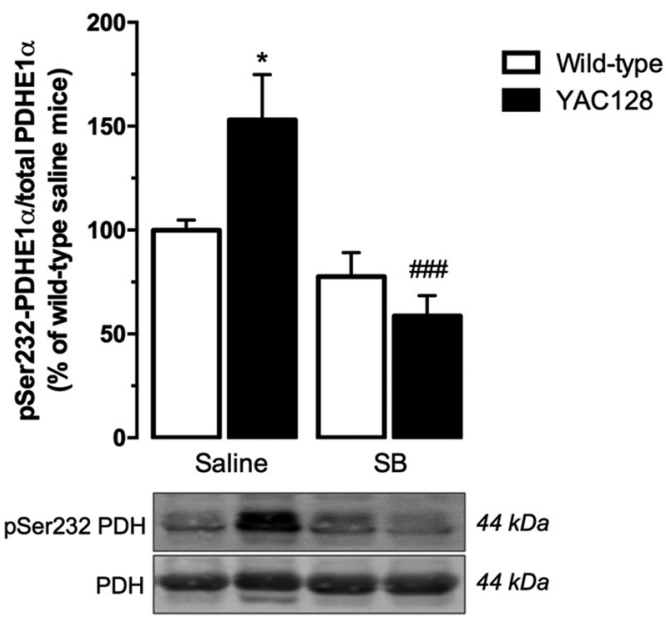

D $\quad 400$

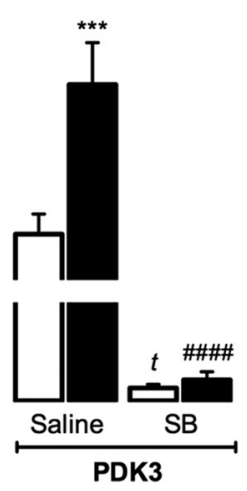

E

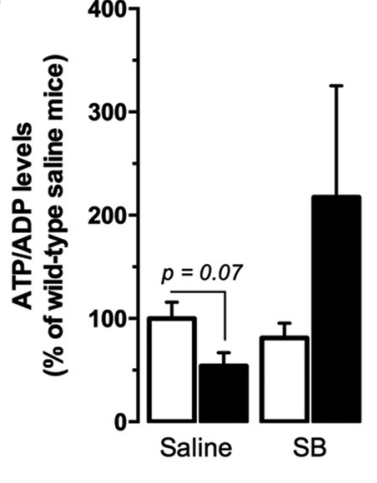

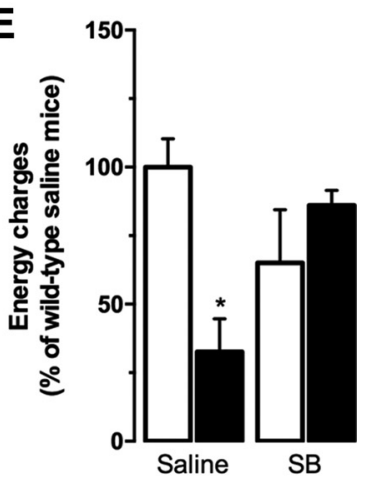

Accelerated task

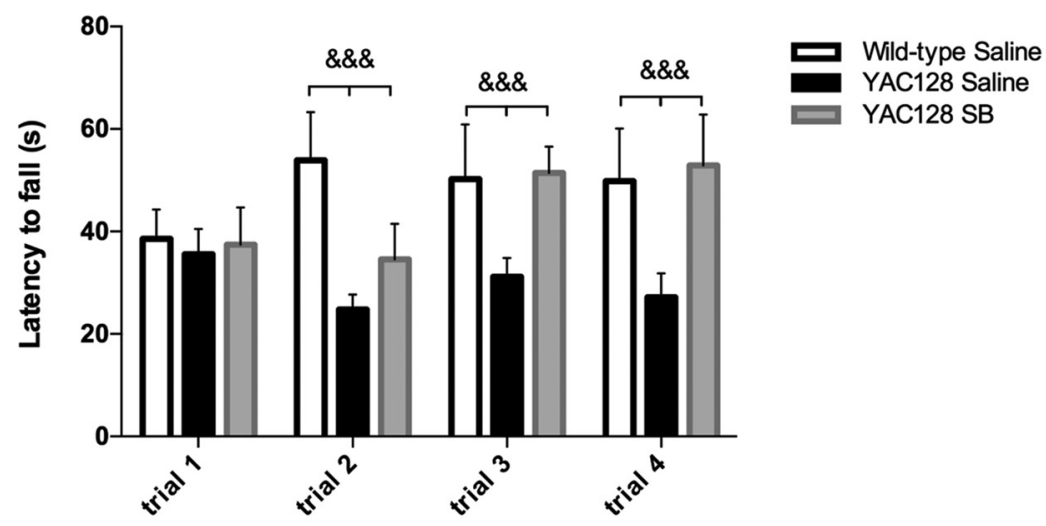

Figure 9. SB treatment recovers PDH function, energy metabolism, and motor coordination in YAC128 mice. Histone 3 acetylation (AcH3; $n=6 / 7 ; A)$, PDH E1 alpha subunit phosphorylation at Ser232 $(n=5 ; B)$, relative mRNA expression of PDK1-3 $(n=6 / 8 ; C)$, ATP/ADP ratio $(n=4 / 5 ; D)$, and energy charge $(n=4 / 5 ; \boldsymbol{E})$ were analyzed in cortical brain fractions from YAC128 (HD53 line) and wild-type mice after treatment with saline (control group) or SB (1 mg/kg/d) for $28 \mathrm{~d}$. Behavioral analysis was performed in a rotarod apparatus in a fixed speed (5 rpm; $\mathrm{motor}$ learning; $\boldsymbol{F}$ ) and in accelerated speed (from 5 to $40 \mathrm{rpm}$; motor coordination; $G)(n=9 / 13)$ and the latency to fall off was recorded, as indicated in the Materials and Methods. Data are shown as the mean \pm SEM of the indicated animals from each treatment. Statistical analysis was performed by two-way ANOVA and revealed a significant interaction between genotype and SB treatment shown in $\boldsymbol{B}\left(F_{(1,31)}=6.113, p=0.0191\right), \boldsymbol{D}\left(F_{(1,14)}=5.627, p=0.0326\right)$, and $\boldsymbol{E}\left(F_{(1,14)}=9.536, p=0.0086\right)$. A strong significant effect of $\mathrm{SB}$ treatment is shown in $\boldsymbol{A}\left(F_{(1,31)}=25.22, p<0.0001\right)$, $\boldsymbol{B}\left(F_{(1,31)}=16.08, p=0.0004\right)$, and $\boldsymbol{G}\left(F_{(1,58)}=16,90, p=0.0001\right)$. In $\boldsymbol{G}$, there is a significant effect of the genotype $\left(F_{(1,67)}=14,66, p=0.0003\right)$. Statistical significance: ${ }^{*} p<0.05$, ${ }^{* *} p<0.01$, ${ }^{* * *} p<0.001$, and ${ }^{* * *} p<0.0001$ compared with wild-type saline-treated group; ${ }^{* \#} p<0.01, \# \#<0.001$, and ${ }^{\# \# \#} p<0.0001$ compared with the respective saline-treated group; and \&\&\& $p<0.001$ between the three cohorts of mice throughout trials 2 to 4 by two-way ANOVA followed by Bonferroni post test and by Student's $t$ test: ${ }^{t} p<0.05$ (in $C$ ). 


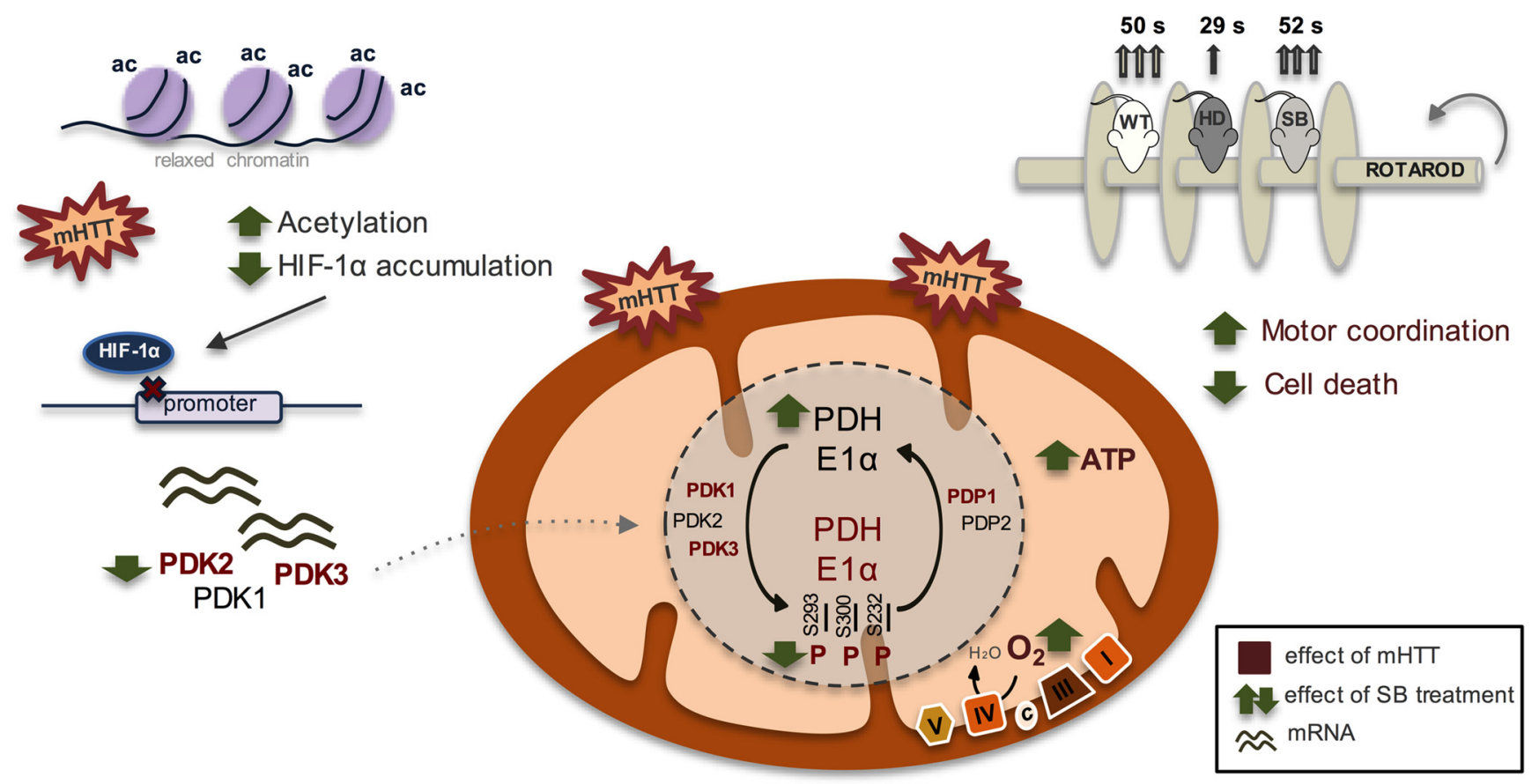

Figure 10. PDH as a therapeutic target in HD: effect of sodium butyrate. Expression of full-length mutant huntingtin caused decreased cell viability associated with decreased mitochondrial respiration and ATP levels and increased ROS levels. Mitochondrial dysfunction in mutant cells was linked to decreased PDH activity. Decreased PDH E1alpha protein levels and increased PDH phosphorylation/inactivation at all three regulatory sites (at Ser293, Ser300 and Ser232) accounted for by this decrease as a consequence of increased protein levels of PDK1 and PDK3 and decreased levels of PDP1c in HD striatal cells and enhanced PDK1-3 mRNA levels in YAC128 mouse brain cortex. SB, as an HDAC class I and Ila inhibitor, significantly increased histone H3 acetylation. Under these conditions, decreased levels of HIF- $1 \alpha$ (which, when acetylated, is degraded by the proteasome) might decrease PDK transcription. Indeed, SB treatment reduced PDK1 (in YAC128 mice only), PDK2, and PDK3 mRNA levels and consequently PDH phosphorylation, culminating in increased PDH activity, mitochondrial respiration, and ATP production. Behavior analysis revealed that SB treatment increased the latency to fall off of the rotarod in YAC128 mice, equaling the time of vehicle-treated wild-type mice. Data suggest that HDACls, particularly SB, ameliorate mitochondrial metabolic function in HD through expression of PDKs and modified PDH activity, which leads to an improved HD phenotype. In this scheme, the text in red represents an increased effect induced by full-length mutant huntingtin compared with the control. The green arrows show the changes induced by SB treatment.

degradation might explain modified protein levels of PDH E1alpha, PDK1, PDK3, and PDP1c. Conversely, saline-treated YAC128 mice showed increased mRNA expression of PDK1-3. An increase in ROS levels in mutant cells may also contribute to inhibit PDH activity because this enzyme was shown to suffer oxidative modifications (Vlessis et al., 1991; Tabatabaie et al., 1996; Samikkannu et al., 2003). Indeed, $\mathrm{H}_{2} \mathrm{O}_{2}$-induced oxidative stress was shown to activate PDK1 (Prasad et al., 2000).

The central role of PDH in cellular bioenergetics makes it a suitable therapeutic target to revert bioenergetic changes in HD. DCA ameliorates PDH deficits by increasing PDH activity through decreased activity of its inhibitory kinases, PDKs, and also by decreasing PDH Elalpha subunit turnover (Morten et al., 1998; Fouque et al., 2003). DCA was shown previously to have beneficial effects in R6/2 and N171-82Q HD mouse models by restoring the active form of PDH (Andreassen et al., 2001). The evidence that DCA decreases apoptosis in mutant cells suggests that altered mitochondrial bioenergetics plays an important role in cell death. Importantly, DCA increased PDH activity and restored mitochondrial respiration and ROS levels in mutant cells, suggesting that higher ROS in mutant cells could be related to lower NADH/NAD ${ }^{+}$ratio due to PDH deficiency (Ferreira et al., 2011) and/or to a failure of oxidative phosphorylation.

\section{HDACIs and mitochondrial dysfunction}

Transcriptional deregulation is a recognized mechanism of HD pathogenesis (Sugars and Rubinsztein, 2003) and increasing gene transcription with HDACIs is an interesting strategy to recover mitochondrial function and energy metabolism in HD. HDACIs were first described to increase acetylation of histones and other chromatin-associated proteins, but more recent reports showed that these pharmacological compounds also modulate the activity of nonhistone substrates across the cell (Schölz et al., 2015). HDACIs were found to have beneficial effects in HD by reducing cell death (Beal and Ferrante, 2004), ameliorating mitochondrial $\mathrm{Ca}^{2+}$ handling (Oliveira et al., 2006), dynamics (Guedes-Dias et al., 2015), and metabolism (Jia et al., 2012). HDACIs were also shown to ameliorate the axonal transport in HD cells (Dompierre et al., 2007) and the neurodegenerative phenotype in HD mice (Ferrante et al., 2003; Thomas et al., 2008).

Here, we show that exposure to HDACIs enhances H3 acetylation and STHdh $h^{\mathrm{Q} 11 / \mathrm{Q} 111}$ cell viability, suggesting that altered gene expression may be linked to neuronal death in HD. Importantly, PDH dysfunction in mutant cells could be reversed by HDACIs. Both PB $(250 \mu \mathrm{M})$ and SB $(500 \mu \mathrm{M})$ increased PDH E1alpha subunit protein levels in mutant cells; moreover, SB decreased the phosphorylation of Elalpha subunit at all regulatory sites, whereas PB decreased Ser 293 phosphorylation. This alteration in PDH phosphorylation suggests that HDACIs interfere with enzymes that regulate $\mathrm{PDH}$ phosphorylation, namely PDKs and PDPs, and/or with related transcription factors (Rardin et al., 2009), supporting a broader action of HDACIs beyond histones as nuclear targets.

Several lines of evidence propose that mitochondrial ROS are sufficient for the stabilization of HIF- $1 \alpha$ under normoxia (Brunelle et al., 2005; Kaelin, 2005). Under these conditions, HIF- $1 \alpha$ escapes degradation and translocates to the nucleus, initiating the transcription of several metabolism-related genes, in- 
cluding PDK1-3 (Kim et al., 2006; Prigione et al., 2014), culminating in decreased $\mathrm{PDH}$ activity. We observed that the HDACI SB produced a marked inhibition of HIF- $1 \alpha$ accumulation, suggesting increased degradation. Earlier studies demonstrated that therapeutic concentrations of HDACI are sufficient to repress HIF- $1 \alpha$ activation (Fath et al., 2006; Kong et al., 2006; Kim et al., 2007). Acetylation of HIF- $1 \alpha$ (at Lys532) enhances its ubiquitination, targeting HIF- $1 \alpha$ for proteasomal degradation (Jeong et al., 2002; Kim et al., 2007). Therefore, SB-mediated protection in mutant cells occurs through modulation of HIF- $1 \alpha$ degradation, which may decrease mRNA expression of PDK2 and PDK3, enhancing PDH E1alpha activity. Indeed, PDK and PDP activities have been described to be mainly regulated by changes in gene expression (Harris et al., 2002; Sugden and Holness, 2006). The isoenzyme PDK3 was found to have high specific activity and an $\sim 2$-fold higher ability to incorporate phosphate than PDK2 (Bowker-Kinley et al., 1998; Kolobova et al., 2001). In agreement, genetic suppression of PDK3 reduced PDH E1alpha sites 1 and 2 phosphorylation, greatly increasing mitochondrial respiration in mutant cells, corroborating the previous hypothesis. Analysis of the mRNA levels of PDK1-3 and PDH phosphorylation in SB-treated YAC128 mice confirmed the relevance of data obtained in striatal cells. We found increased PDH E1alpha phosphorylation (at Ser232) and mRNA expression of PDK1-3 in the cortex of YAC128 mice, which were largely reduced in SB-treated animals. Moreover, SB-treated YAC128 mice showed improved cortical energy levels and increased $\mathrm{H} 3$ acetylation. Of major importance, SB treatment improved YAC128 motor learning and function at conditions at which it also rescued $\mathrm{PDH}$ activity, reinforcing the protective role of this HDACI.

We have provided evidence of HDACIs as potential neuroprotective compounds in neurodegeneration research and therapy; however, major challenges remain in the identification of their primary targets because it is difficult to reconcile whether the observed effects are exclusively at the epigenetic level. SB treatment was reported to potentially increase 3112 acetylation sites in a cell-based acetylome analysis (Schölz et al., 2015). Indeed, in addition to nuclear effects, HDACIs, including SB, might modulate mitochondrial targets directly. PDH E1alpha was reported to be acetylated at Lys321, facilitating Ser293 phosphorylation and reducing PDC activity (Fan et al., 2014), in contrast to the effect of HDACI found in the present study. In turn, acetylation of the PDH E2 subunit increased PDC activity (Behal et al., 1993). In the latter case, lysine acetylation could prevent lysine ubiquitination, preventing protein degradation by proteasomal or lysosomal machineries and resulting in increased protein halflife (Sadoul et al., 2008; Zhao et al., 2010). Conversely, as with HIF- $1 \alpha$ at Lys532, lysine acetylation can promote ubiquitination, leading to protein degradation. Therefore, in addition to the indirect effect of HDACIs on PDH activity via PDK gene transcription through regulation of HIF- $1 \alpha$ stabilization, these compounds may interfere with protein turnover directly by increasing acetylation and possibly modulating the ubiquitination and degradation processes. Therefore, future studies will benefit from the identification/design of HDAC-selective inhibitors.

Overall, this work brings a better understanding of mitochondrial dysfunction in HD-affected cells by providing evidence for a central role of PDH deregulation. Our data provide support for $\mathrm{PDH}$ as a promising therapeutic target in $\mathrm{HD}$, as summarized in Figure 10. In addition, SB was shown to be a promising neuroprotective agent for the treatment of mitochondrial bioenergetic dysfunction in HD striatal cells and YAC128 mice by decreasing the expression of the most abundant PDK isoforms.

\section{References}

Andreassen OA, Ferrante RJ, Huang HM, Dedeoglu A, Park L, Ferrante KL, Kwon J, Borchelt DR, Ross CA, Gibson GE, Beal MF (2001) Dichloroacetate exerts therapeutic effects in transgenic mouse models of Huntington's disease. Ann Neurol 50:112-117. CrossRef Medline

Beal MF, Ferrante RJ (2004) Experimental therapeutics in transgenic mouse models of Huntington's disease. Nat Rev Neurosci 5:373-384. CrossRef Medline

Behal RH, Buxton DB, Robertson JG, Olson MS (1993) Regulation of the pyruvate dehydrogenase multienzyme complex. Annu Rev Nutr 13:497520. Medline

Benn CL, Sun T, Sadri-Vakili G, McFarland KN, DiRocco DP, Yohrling GJ, Clark TW, Bouzou B, Cha JH (2008) Huntingtin modulates transcription, occupies gene promoters in vivo, and binds directly to DNA in a polyglutamine-dependent manner. J Neurosci 28:10720-10733. CrossRef Medline

Borovecki F, Lovrecic L, Zhou J, Jeong H, Then F, Rosas HD, Hersch SM, Hogarth P, Bouzou B, Jensen RV, Krainc D (2005) Genome-wide expression profiling of human blood reveals biomarkers for Huntington's disease. Proc Natl Acad Sci U S A 102:11023-11028. CrossRef Medline

Bowker-Kinley MM, Davis WI, Wu P, Harris RA, Popov KM (1998) Evidence for existence of tissue-specific regulation of the mammalian pyruvate dehydrogenase complex. Biochem J 329:191-196. CrossRef Medline

Brett AC, Rosenstock TR, Rego AC (2014) Current therapeutic advances in patients and experimental models of Huntington's Disease. Curr Drug Targets 15:313-334. CrossRef Medline

Brunelle JK, Bell EL, Quesada NM, Vercauteren K, Tiranti V, Zeviani M, Scarpulla RC, Chandel NS (2005) Oxygen sensing requires mitochondrial ROS but not oxidative phosphorylation. Cell Metab 1:409-414. CrossRef Medline

Butterworth J, Yates CM, Reynolds GP (1985) Distribution of phosphateactivated glutaminase, succinic dehydrogenase, pyruvate dehydrogenase and gamma-glutamyl transpeptidase in post-mortem brain from Huntington's disease and agonal cases. J Neurol Sci 67:161-171. CrossRef Medline

Chandel NS, Maltepe E, Goldwasser E, Mathieu CE, Simon MC, Schumacker PT (1998) Mitochondrial reactive oxygen species trigger hypoxia-induced transcription. Proc Natl Acad Sci U S A 95:1171511720. CrossRef Medline

Cui L, Jeong H, Borovecki F, Parkhurst CN, Tanese N, Krainc D (2006) Transcriptional repression of PGC-1alpha by mutant huntingtin leads to mitochondrial dysfunction and neurodegeneration. Cell 127:59-69. CrossRef Medline

Cunha-Oliveira T, Ferreira IL, Cristina A (2012) Consequences of mitochondrial dysfunction in Huntington's disease and protection via phosphorylation pathways. In: InTech: Huntington's disease: core concepts and current advances. Available from: https://estudogeral.sib.uc.pt/handle/10316/18507.

Daitoku H, Sakamaki J, Fukamizu A (2011) Regulation of FoxO transcription factors by acetylation and protein-protein interactions. Biochim Biophys Acta 1813:1954-1960. CrossRef Medline

Damiano M, Galvan L, Déglon N, Brouillet E (2010) Mitochondria in Huntington's disease. Biochim Biophys Acta 1802:52-61. CrossRef Medline

Dompierre JP, Godin JD, Charrin BC, Cordelières FP, King SJ, Humbert S, Saudou F (2007) Histone deacetylase 6 inhibition compensates for the transport deficit in Huntington's disease by increasing tubulin acetylation. J Neurosci 27:3571-3583. CrossRef Medline

Fan J et al. (2014) Tyr phosphorylation of PDP1 toggles recruitment between ACAT1 and SIRT3 to regulate the pyruvate dehydrogenase complex. Mol Cell 53:534-548. CrossRef Medline

Fath DM, Kong X, Liang D, Lin Z, Chou A, Jiang Y, Fang J, Caro J, Sang N (2006) Histone deacetylase inhibitors repress the transactivation potential of hypoxia-inducible factors independently of direct acetylation of HIF-alpha. J Biol Chem 281:13612-13619. CrossRef Medline

Ferrante RJ, Kubilus JK, Lee J, Ryu H, Beesen A, Zucker B, Smith K, Kowall NW, Ratan RR, Luthi-Carter R, Hersch SM (2003) Histone deacetylase inhibition by sodium butyrate chemotherapy ameliorates the neurodegenerative phenotype in Huntington's disease mice. J Neurosci 23:94189427. Medline 
Ferreira IL, Nascimento MV, Ribeiro M, Almeida S, Cardoso SM, Grazina M, Pratas J, Santos MJ, Januário C, Oliveira CR, Rego AC (2010) Mitochondrial-dependent apoptosis in Huntington's disease human cybrids. Exp Neurol 222:243-255. CrossRef Medline

Ferreira IL, Cunha-Oliveira T, Nascimento MV, Ribeiro M, Proença MT, Januário C, Oliveira CR, Rego AC (2011) Bioenergetic dysfunction in Huntington's disease human cybrids. Exp Neurol 231:127-134. CrossRef Medline

Fouque F, Brivet M, Boutron A, Vequaud C, Marsac C, Zabot MT, Benelli C (2003) Differential effect of DCA treatment on the pyruvate dehydrogenase complex in patients with severe PDHC deficiency. Pediatr Res 53: 793-799. CrossRef Medline

Gil JM, Rego AC (2008) Mechanisms of neurodegeneration in Huntington's disease. Eur J Neurosci 27:2803-2820 CrossRef Medline

Guedes-Dias P, de Proença J, Soares TR, Leitão-Rocha A, Pinho BR, Duchen MR, Oliveira JM (2015) HDAC6 inhibition induces mitochondrial fusion, autophagic flux and reduces diffuse mutant huntingtin in striatal neurons. Biochim Biophys Acta 1852:2484-2493. CrossRef Medline

Harris RA, Bowker-Kinley MM, Huang B, Wu P (2002) Regulation of the activity of the pyruvate dehydrogenase complex. Adv Enzyme Regul 42:249-259.

Hogarth P, Lovrecic L, Krainc D (2007) Sodium phenylbutyrate in Huntington's disease: a dose-finding study. Mov Disord 22:1962-1964. CrossRef Medline

Jenkins BG, Koroshetz WJ, Beal MF, Rosen BR (1993) Evidence for impairment of energy metabolism in vivo in Huntington's disease using localized 1H NMR spectroscopy. Neurology 43:2689-2695. CrossRef Medline

Jenkins BG, Rosas HD, Chen YC, Makabe T, Myers R, MacDonald M, Rosen BR, Beal MF, Koroshetz WJ (1998) 1H NMR spectroscopy studies of Huntington's disease: Correlations with CAG repeat numbers. Neurology 50:1357-1365. CrossRef Medline

Jeong JW, Bae MK, Ahn MY, Kim SH, Sohn TK, Bae MH, Yoo MA, Song EJ, Lee KJ, Kim KW (2002) Regulation and destabilization of HIF-1 $\alpha$ by ARD1-mediated acetylation. Cell 111:709-720. CrossRef Medline

Jeong JY, Jeoung NH, Park KG, Lee IK (2012) Transcriptional regulation of pyruvate dehydrogenase kinase. Diabetes Metab J 36:328-335. CrossRef Medline

Jia H, Pallos J, Jacques V, Lau A, Tang B, Cooper A, Syed A, Purcell J, Chen Y, Sharma S, Sangrey GR, Darnell SB, Plasterer H, Sadri-Vakili G, Gottesfeld JM, Thompson LM, Rusche JR, Marsh JL, Thomas EA (2012) Histone deacetylase (HDAC) inhibitors targeting HDAC 3 and HDAC1 ameliorate polyglutamine-elicited phenotypes in model systems of Huntington's disease. Neurobiol Dis 46:351-361. CrossRef Medline

Jones LL, McDonald DA, Borum PR (2010) Acylcarnitines: role in brain. Prog Lipid Res 49:61-75. CrossRef Medline

Kaelin WG Jr (2005) ROS: really involved in oxygen sensing. Cell Metab 1:357-358. CrossRef Medline

Kalyanaraman B, Darley-Usmar V, Davies KJ, Dennery PA, Forman HJ, Grisham MB, Mann GE, Moore K, Roberts LJ 2nd, Ischiropoulos H (2012) Measuring reactive oxygen and nitrogen species with fluorescent probes: challenges and limitations. Free Radic Biol Med 52:1-6. CrossRef Medline

Karpova T, Danchuk S, Kolobova E, Popov KM (2003) Characterization of the isozymes of pyruvate dehydrogenase phosphatase: Implications for the regulation of pyruvate dehydrogenase activity. Biochim Biophys Acta 1652:126-135. CrossRef Medline

Kiilerich K, Adser H, Jakobsen AH, Pedersen PA, Hardie DG, Wojtaszewski JF, Pilegaard H (2010) PGC-1alpha increases PDH content but does not change acute PDH regulation in mouse skeletal muscle. Am J Physiol Regul Integr Comp Physiol 299:R1350-R1359. CrossRef Medline

Kim JW, Tchernyshyov I, Semenza GL, Dang CV (2006) HIF-1-mediated expression of pyruvate dehydrogenase kinase: a metabolic switch required for cellular adaptation to hypoxia. Cell Metab 3:177-185. CrossRef Medline

Kim SH, Jeong JW, Park JA, Lee JW, Seo JH, Jung BK, Bae MK, Kim KW (2007) Regulation of the HIF-1 alpha stability by histone deacetylases. Oncol Rep 17:647-651. Medline

Kolobova E, Tuganova A, Boulatnikov I, Popov KM (2001) Regulation of pyruvate dehydrogenase activity through phosphorylation at multiple sites. Biochem J 358:69-77. Medline

Kong X, Lin Z, Liang D, Fath D, Sang N, Caro J (2006) Histone deacetylase inhibitors induce VHL and ubiquitin-independent proteasomal degrada- tion of hypoxia-inducible factor 1alpha. Mol Cell Biol 26:2019-2028. CrossRef Medline

Koroshetz WJ, Jenkins BG, Rosen BR, Beal MF (1997) Energy metabolism defects in Huntington's disease and effects of coenzyme Q10. Ann Neurol 41:160-165. CrossRef Medline

Kuhl DE, Phelps ME, Markham CH, Metter EJ, Riege WH, Winter J (1982) Cerebral metabolism and atrophy in Huntington's disease determined by 18FDG and computed tomographic scan. Ann Neurol 12:425-434. CrossRef Medline

Kuwert T, Lange HW, Langen KJ, Herzog H, Aulich A, Feinendegen LE (1989) Cerebral glucose consumption measured by PET in patients with and without psychiatric symptoms of Huntington's disease. Psychiatry Res 29:361-362. CrossRef Medline

Lu CW, Lin SC, Chen KF, Lai YY, Tsai SJ (2008) Induction of pyruvate dehydrogenase kinase- 3 by hypoxia-inducible factor- 1 promotes metabolic switch and drug resistance. J Biol Chem 283:28106-28114. CrossRef Medline

Milakovic T, Johnson GV (2005) Mitochondrial respiration and ATP production are significantly impaired in striatal cells expressing mutant huntingtin. J Biol Chem 280:30773-30782. CrossRef Medline

Mochel F, Haller RG (2011) Energy deficit in Huntington disease: Why it matters. J Clin Invest 121:493-499. CrossRef Medline

Morten KJ, Caky M, Matthews PM (1998) Stabilization of the pyruvate dehydrogenase Elalpha subunit by dichloroacetate. Neurology 51:13311335. CrossRef Medline

Movafagh S, Crook S, Vo K (2015) Regulation of hypoxia-inducible Factor-1a by reactive oxygen species: new developments in an old debate. J Cell Biochem 116:696-703. CrossRef Medline

Naia L, Ferreira IL, Cunha-Oliveira T, Duarte AI, Ribeiro M, Rosenstock TR, Laço MN, Ribeiro MJ, Oliveira CR, Saudou F, Humbert S, Rego AC (2015) Activation of IGF-1 and insulin signaling pathways ameliorate mitochondrial function and energy metabolism in Huntington's disease human lymphoblasts. Mol Neurobiol 51:331-348. CrossRef Medline

Naia L, Ribeiro M, Rodrigues J, Duarte AI, Lopes C, Rosenstock TR, Hayden MR, Rego AC (2016a) Insulin and IGF-1 regularize energy metabolites in neural cells expressing full-length mutant huntingtin. Neuropeptides 58:73-81. CrossRef Medline

Naia L, Rosenstock TR, Oliveira AM, Oliveira-Sousa SI, Caldeira GL, Carmo C, Laço MN, Hayden MR, Oliveira CR, Rego AC (2016b) Comparative mitochondrial-based protective effects of resveratrol and nicotinamide in Huntington's disease models. Mol Neurobiol. Advance online publication. Retrieved February 15, 2017. CrossRef Medline

Oliveira JM, Chen S, Almeida S, Riley R, Gonçalves J, Oliveira CR, Hayden MR, Nicholls DG, Ellerby LM, Rego AC (2006) Mitochondrialdependent Ca2 + handling in Huntington's disease striatal cells: effect of histone deacetylase inhibitors. J Neurosci 26:11174-11186. CrossRef Medline

Papandreou I, Cairns RA, Fontana L, Lim AL, Denko NC (2006) HIF-1 mediates adaptation to hypoxia by actively downregulating mitochondrial oxygen consumption. Cell Metab 3:187-197. CrossRef Medline

Patel MS, Korotchkina LG (2006) Regulation of the pyruvate dehydrogenase complex. Biochem Soc Trans 34:217-222. Medline

Perluigi M, Poon HF, Maragos W, Pierce WM, Klein JB, Calabrese V, Cini C, De Marco C, Butterfield DA (2005) Proteomic analysis of protein expression and oxidative modification in r6/2 transgenic mice: a model of Huntington disease. Mol Cell Proteomics 4:1849-1861. CrossRef Medline

Prasad N, Topping RS, Zhou D, Decker SJ (2000) Oxidative stress and vanadate induce tyrosine phosphorylation of phosphoinositide-dependent kinase 1 (PDK1). Biochemistry 39:6929-6935. CrossRef Medline

Prigione A, Rohwer N, Hoffmann S, Mlody B, Drews K, Bukowiecki R, Blümlein K, Wanker EE, Ralser M, Cramer T, Adjaye J (2014) HIF1 $\alpha$ modulates cell fate reprogramming through early glycolytic shift and upregulation of PDK1-3 and PKM2. Stem Cells 32:364-376. CrossRef Medline

Rardin MJ, Wiley SE, Naviaux RK, Murphy AN, Dixon JE (2009) Monitoring phosphorylation of the pyruvate dehydrogenase complex. Anal Biochem 389:157-164. CrossRef Medline

Ribeiro M, Rosenstock TR, Cunha-Oliveira T, Ferreira IL, Oliveira CR, Rego AC (2012) Glutathione redox cycle dysregulation in Huntington's disease knock-in striatal cells. Free Radic Biol Med 53:1857-1867. CrossRef Medline 
Ribeiro M, Silva AC, Rodrigues J, Naia L, Rego AC (2013) Oxidizing effects of exogenous stressors in Huntington's disease knock-in striatal cellsprotective effect oflcystamine and creatine. Toxicol Sci 136:487-499. CrossRef Medline

Ribeiro M, Rosenstock TR, Oliveira AM, Oliveira CR, Rego AC (2014) Insulin and IGF-1 improve mitochondrial function in a PI-3K/Aktdependent manner and reduce mitochondrial generation of reactive oxygen species in Huntington's disease knock-in striatal cells. Free Radic Biol Med 74:129-144. CrossRef Medline

Sadoul K, Boyault C, Pabion M, Khochbin S (2008) Regulation of protein turnover by acetyltransferases and deacetylases. Biochimie 90:306-312. CrossRef Medline

Salceda S, Caro J (1997) Hypoxia-inducible factor 1?? (HIF-1??) protein is rapidly degraded by the ubiquitin-proteasome system under normoxic conditions. Its stabilization by hypoxia depends on redox-induced changes. J Biol Chem 272:22642-22647. CrossRef Medline

Samikkannu T, Chen CH, Yih LH, Wang AS, Lin SY, Chen TC, Jan KY (2003) Reactive oxygen species are involved in arsenic trioxide inhibition of pyruvate dehydrogenase activity. Chem Res Toxicol 16:409-414. CrossRef Medline

Schatz G (1995) Mitochondria: beyond oxidative phosphorylation. Biochim Biophys Acta 1271:123-126. Medline

Schölz C, Weinert BT, Wagner SA, Beli P, Miyake Y, Qi J, Jensen LJ, Streicher W, McCarthy AR, Westwood NJ, Lain S, Cox J, Matthias P, Mann M, Bradner JE, Choudhary C (2015) Acetylation site specificities of lysine deacetylase inhibitors in human cells. Nat Biotechnol 33:415-423. CrossRef Medline

Silva AC, Almeida S, Laço M, Duarte AI, Domingues J, Oliveira CR, Januário C, Rego AC (2013) Mitochondrial respiratory chain complex activity and bioenergetic alterations in human platelets derived from presymptomatic and symptomatic Huntington's disease carriers. Mitochondrion 13:801-809. CrossRef Medline

Slow EJ, van Raamsdonk J, Rogers D, Coleman SH, Graham RK, Deng Y, Oh R, Bissada N, Hossain SM, Yang YZ, Li XJ, Simpson EM, Gutekunst CA, Leavitt BR, Hayden MR (2003) Selective striatal neuronal loss in a YAC128 mouse model of Huntington disease. Hum Mol Genet 12:15551567. CrossRef Medline

Sorbi S, Bird ED, Blass JP (1983) Decreased pyruvate dehydrogenase complex activity in Huntington and Alzheimer brain. Ann Neurol 13:72-78. CrossRef Medline

Sorolla MA, Rodríguez-Colman MJ, Tamarit J, Ortega Z, Lucas JJ, Ferrer I, Ros J, Cabiscol E (2010) Protein oxidation in Huntington disease affects energy production and vitamin B6 metabolism. Free Radic Biol Med 49:612-621. CrossRef Medline
Struhl K (1998) Histone acetylation and transcriptional regulatory mechanisms. Genes Dev 12:599-606. CrossRef Medline

Sugars KL, Rubinsztein DC (2003) Transcriptional abnormalities in Huntington disease. Trends Genet 19:233-238. CrossRef Medline

Sugden MC, Holness MJ (2006) Mechanisms underlying regulation of the expression and activities of the mammalian pyruvate dehydrogenase kinases. Arch Physiol Biochem 112:139-149. CrossRef Medline

Tabatabaie T, Potts JD, Floyd RA (1996) Reactive oxygen species-mediated inactivation of pyruvate dehydrogenase. Arch Biochem Biophys 336:290 296. CrossRef Medline

Thomas EA, Coppola G, Desplats PA, Tang B, Soragni E, Burnett R, Gao F, Fitzgerald KM, Borok JF, Herman D, Geschwind DH, Gottesfeld JM (2008) The HDAC inhibitor $4 \mathrm{~b}$ ameliorates the disease phenotype and transcriptional abnormalities in Huntington's disease transgenic mice. Proc Natl Acad Sci U S A 105:15564-15569. CrossRef Medline

Trettel F, Rigamonti D, Hilditch-Maguire P, Wheeler VC, Sharp AH, Persichetti F, Cattaneo E, MacDonald ME (2000) Dominant phenotypes produced by the HD mutation in STHdh(Q111) striatal cells. Hum Mol Genet 9:2799-2809. CrossRef Medline

Valenza M, Carroll JB, Leoni V, Bertram LN, Björkhem I, Singaraja RR, Di Donato S, Lutjohann D, Hayden MR, Cattaneo E (2007) Cholesterol biosynthesis pathway is disturbed in YAC128 mice and is modulated by huntingtin mutation. Hum Mol Genet 16:2187-2198. CrossRef Medline

Van Raamsdonk JM, Pearson J, Slow EJ, Hossain SM, Leavitt BR, Hayden MR (2005) Cognitive dysfunction precedes neuropathology and motor abnormalities in the YAC128 mouse model of Huntington's disease. J Neurosci 25:4169-4180. CrossRef Medline

Van Raamsdonk JM, Gibson WT, Pearson J, Murphy Z, Lu G, Leavitt BR, Hayden MR (2006) Body weight is modulated by levels of full-length huntingtin. Hum Mol Genet 15:1513-1523. CrossRef Medline

Vlessis AA, Muller P, Bartos D, Trunkey D (1991) Mechanism of peroxideinduced cellular injury in cultured adult cardiac myocytes. FASEB J 5:2600-2605. Medline

Zhai W, Jeong H, Cui L, Krainc D, Tjian R (2005) In vitro analysis of huntingtin-mediated transcriptional repression reveals multiple transcription factor targets. Cell 123:1241-1253. CrossRef Medline

Zhao S, et al. (2010) Regulation of cellular metabolism by protein lysine acetylation. Science 327:1000-1004. CrossRef Medline

Zhou Q, Lam PY, Han D, Cadenas E (2009) Activation of c-Jun-N-terminal kinase and decline of mitochondrial pyruvate dehydrogenase activity during brain aging. FEBS Lett 583:1132-1140. CrossRef Medline

Zuccato C, Valenza M, Cattaneo E (2010) Molecular mechanisms and potential therapeutical targets in Huntington's disease. Physiol Rev 90:905981. CrossRef Medline 